\title{
Work Plan of the Neversink Watershed Study in the Catskill Mountains of Southeastern New York
}

By Gregory B. Lawrence, Douglas A. Burns, Peter S. Murdoch, Barry Baldigo, and Yvonne H. Baevsky

Prepared in cooperation with the

New York City Department of Environmental Protection

U.S. Geological Survey Open-File Report 94-368

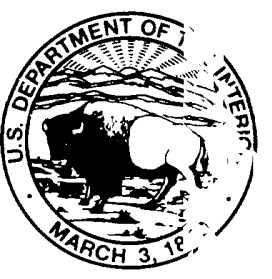




\title{
DEPARTMENT OF THE INTERIOR \\ BRUCE BABBITT, Secretary
}

\author{
U.S. GEOLOGICAL SURVEY \\ Gordon P. Eaton, Director
}

For additional information write to:

Copies of this report may be purchased from:

U.S. Geological Survey

P.O. Box 1669

Albany, N.Y. 12201

(518) $472-3107$
U.S. Geological Survey

Earth Science Information Center

Open-File Reports Section

Box 25286, MS 517

Denver Federal Center

Denver, CO 80225 


\section{CONTENTS}

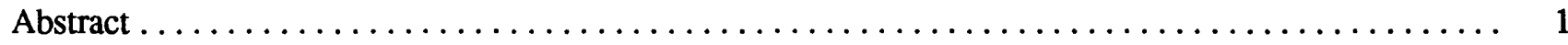

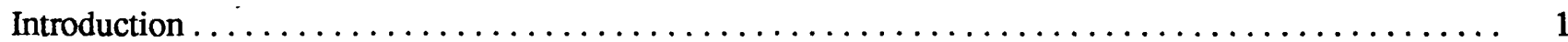

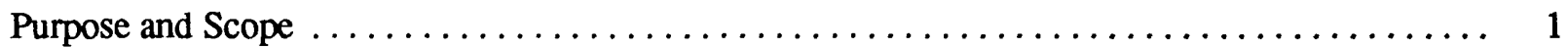

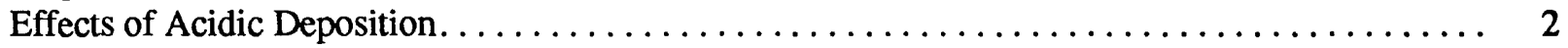

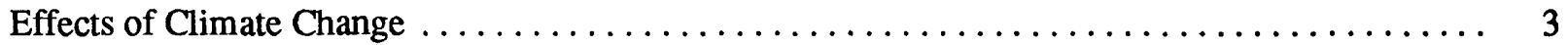

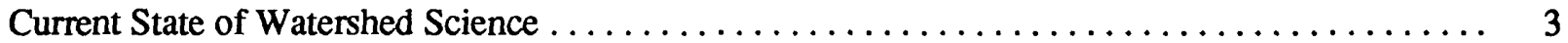

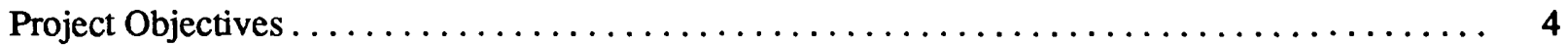

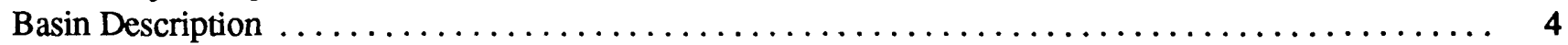

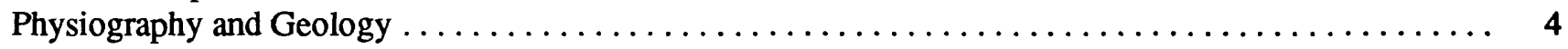

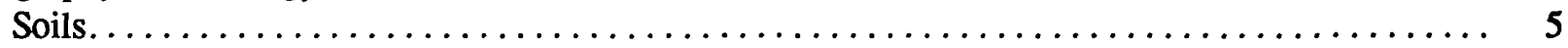

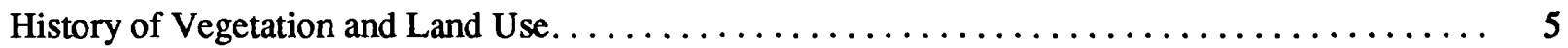

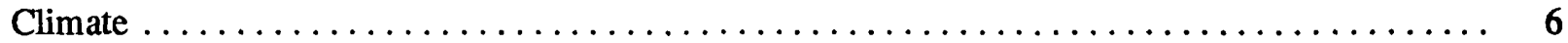

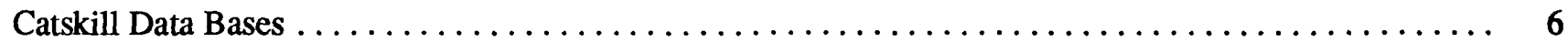

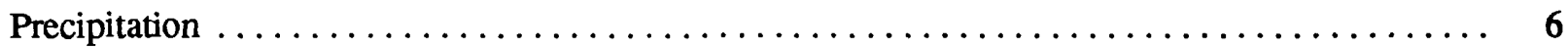

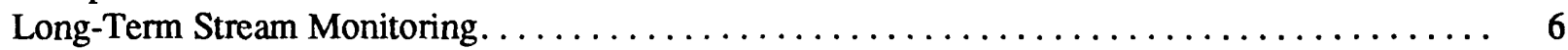

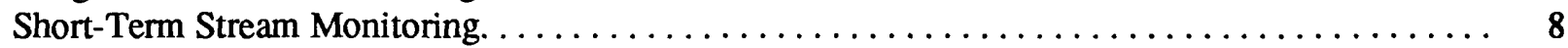

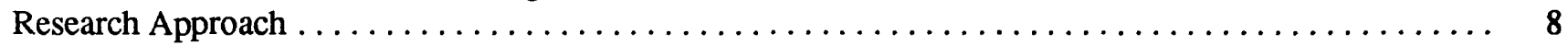

Topic A. Small (First-Order) Watersheds $\ldots \ldots \ldots \ldots \ldots \ldots \ldots \ldots \ldots \ldots \ldots \ldots \ldots \ldots \ldots$

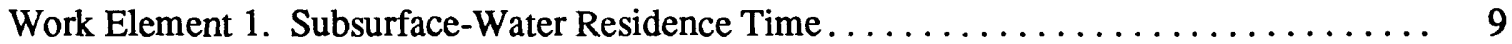

Work Element 2. Hillslope Gradients of Soil Chemistry $\ldots \ldots \ldots \ldots \ldots \ldots \ldots \ldots \ldots \ldots \ldots$

Work Element 3. Extrapolation of Relations to Other First-Order Watersheds . . . . . . . 11

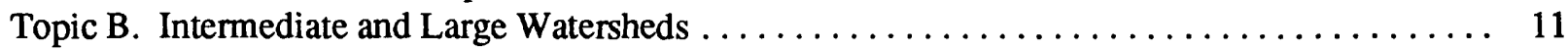

Work Element 1. Spatial Controls in Intermediate and Large Watersheds. . . . . . . . 12

Work Element 2. Effect of Watershed Size on Temporal Variations in Stream Chemistry 12

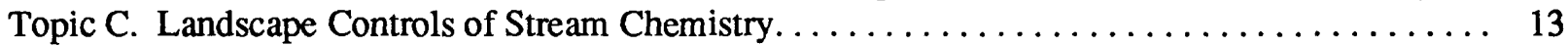

Work Element 1. Identifying the Effect of Landscapes on Neversink River-Water Quality . . 14

Work Element 2. Modeling the Sources of Landscape Effects on Stream-Water Quality ... 15

Topic D. Nonconservative Transport of Nitrate and Aluminum in Stream Water . . . . . . . . . 15

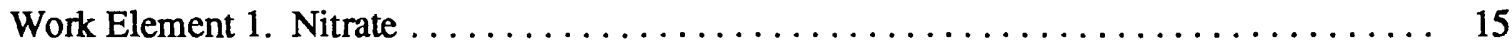

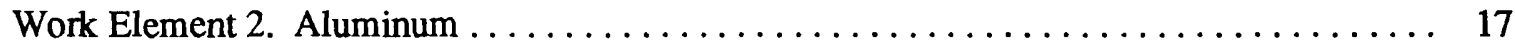

Topic E. Nitrogen Cycling $\ldots \ldots \ldots \ldots \ldots \ldots \ldots \ldots \ldots \ldots \ldots \ldots \ldots \ldots \ldots \ldots \ldots \ldots$

Work Element 1. Quantifying Nitrogen Budgets $\ldots \ldots \ldots \ldots \ldots \ldots \ldots \ldots \ldots \ldots$

Topic F. Water Quality and its Effects on Aquatic Biological Communities $\ldots \ldots \ldots \ldots \ldots \ldots 20$

Effects of Acidification on Fish and Invertebrate Populations $\ldots \ldots \ldots \ldots \ldots \ldots \ldots \ldots \ldots$

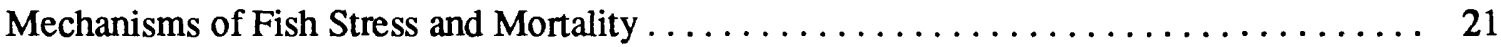

Use of Biological Indices in Characterizing Water Quality $\ldots \ldots \ldots \ldots \ldots \ldots \ldots \ldots \ldots$

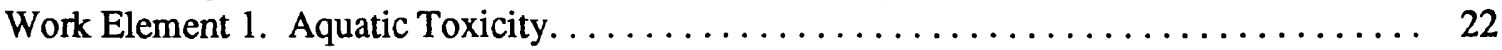

Work Element 2. Integrity of Biological Communities $\ldots \ldots \ldots \ldots \ldots \ldots \ldots \ldots \ldots$

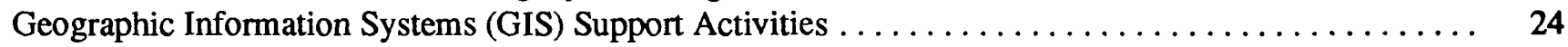

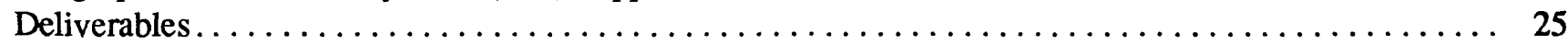

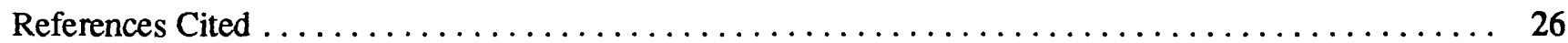

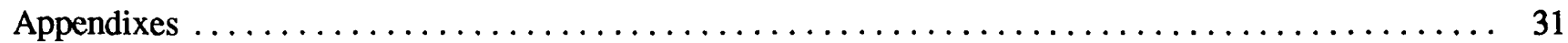

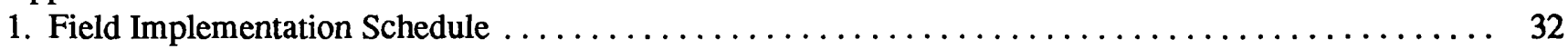

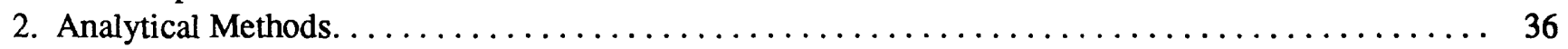

3. Quality-Assurance Plan for Streamflow Measurements $\ldots \ldots \ldots \ldots \ldots \ldots \ldots \ldots \ldots \ldots \ldots$

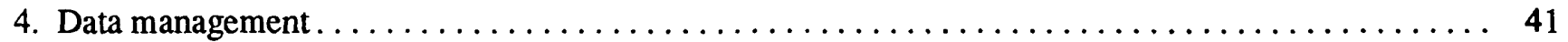




\section{FIGURES}

1. Map of Neversink watershed showing locations of streamflow-gaging stations . . . . . . . . . 2

2. Map of Wildcat and Winnisook watersheds showing locations of measurement sites ......... 9

\section{TABLE}

1. Location, drainage area, and period of record at historical and long-term monitoring sites in the Catskill Mountain region. . . . . . . . . . . . . . . . . . .

\section{CONVERSION FACTORS}

$\begin{array}{lll}\text { Muitipiy } & \text { By } & \text { To obtain } \\ \text { millimeter }(\mathrm{mm}) & 0.03937 & \text { inch } \\ \text { meter }(\mathrm{m}) & 3.281 & \text { foot } \\ \text { kilometer }(\mathrm{km}) & 0.6214 & \text { mile } \\ \text { square kilometers }\left(\mathrm{km}^{2}\right) & 0.3861 & \text { square mile. } \\ \text { hectare }(\text { ha) } & 2.471 & \text { acre } \\ \text { square meter }\left(\mathrm{m}^{2}\right) & 10.76 & \text { square foot } \\ \text { liter }(\mathrm{L}) & 0.2642 & \text { gallon } \\ \text { cubic meter }\left(\mathrm{m}^{3}\right) & 35.31 & \text { cubic foot } \\ \text { cubic meter per day }\left(\mathrm{m}^{3} / \mathrm{d}\right) & 264.2 & \text { gallon per day } \\ \text { liters per second }(\mathrm{L} / \mathrm{s}) & 0.0353 & \text { cubic feet per second } \\ \text { liters per minute }(\mathrm{L} / \mathrm{m}) & 2.118 & \text { cubic feet per minute }\end{array}$

\section{ABBREVIATIONS}

micromoles per liter $(\mu \mathrm{mol} / \mathrm{L})$

Temperature can be converted from degrees Celsius $\left({ }^{\circ} \mathrm{C}\right)$ to degrees Fahrenheit $\left({ }^{\circ} \mathrm{F}\right)$ by the following equation:

$$
{ }^{\circ} \mathrm{F}=9 / 5^{\circ} \mathrm{C}+32
$$

Sea level: In this report "sea level" refers to the National Geodetic Vertical Datum of 1929 (NGVD of 1929) - a geodetic datum derived from a general adjustment of the first-order level nets of both the United States and Canada, formerly called Sea Level datum of 1929. 


\title{
Work Plan of the Neversink Watershed Study in the Catskill Mountains of Southeastern New York
}

\author{
By Gregory B. Lawrence, Douglas A. Burns, Peter S. Murdoch, Barry Baldigo, \\ and Yvonne $\mathrm{H}$. Baevsky
}

\section{Abstract}

The Neversink River drains into the Neversink Reservoir, which is part of the New York City watersupply system in the Catskill Mountains of southeastern New York State. The U.S. Geological Survey (USGS) is conducting a 5-year (1990-95) water-quality assessment of the Neversink River basin to evaluate watershed factors that control stream-water quality over spatial scales ranging from a few hectares to 240 square kilometers. Because the basin contains minimal development, the focus of the assessment is on natural processes and effects of acidic deposition, the factors that most strongly affect surface-water chemistry. The final product is to be a conceptual model of the spatial distribution of the major controls of stream-water quality in the Neversink basin.

The assessment contains six topics of investigation: (1) small watersheds, (2) intermediate and large watersheds, (3) effects of landscape on stream chemistry, (4) effects of nonconservative transport of nitrate and aluminum in stream water, (5) nitrogen cycle, and (6) water quality and its effects on aquatic biological communities. Approaches include streamflow monitoring and chemical analysis of stream water throughout the basin; computerized modeling of flow and stream chemistry through TOPMODEL; spatial analysis of soil chemistry; use of stable isotopes to identify subsurface flowpaths; monitoring wet and dry atmospheric deposition; in-stream nutrient-cycling studies with added tracers; fish shocking and aquatic invertebrate sampling; and onsite fish-bioassay studies. The information collected in this study will be related through a Geographic Information System (GIS) to develop the conceptual model. Because the Neversink basin is minimally affected by human activity, the conceptual model will provide a basis for comparison with other watersheds and provide a foundation for development of a management model that incorporates development scenarios.

\section{INTRODUCTION}

The City of New York relies on five rese voirs in the Catskill Mountains to supply drinking water to 8 million residents. Historically this water has been of high quality, but it could be adversely affecte 1 in the future by changes in land use, continued deposition of atmospheric pollutants, and (or) changes in climate. The need for development of effective waters'ed-management strategies to address these issues prompted the New York City Department of Environment: ${ }^{1}$ Protection (NYCDEP) in 1990 to begin a research investigation, in cooperation with the U.S. Geological Survey (USGS), to evaluate factors that affect water quality in Catskill watersheds. This investigation is be ing done in the Neversink Riyer basin, in the southeaste $n$ part of the Catskill Mountain region of New York S'ate (fig. 1). The USGS is evaluating the watershed ard streamchannel processes that control stream-water chemistry, and the New York State Department of Environmental Protection is concurrently evaluating process?s within the Neversink Reservoir, to which the Neversink River is tributary.

\section{Purpose and Scope}

This report describes in detail the goals, approaches, and expected deliverables of the Neversink Watershed study. Because this report is a workplan, its scope is limited to a presentation of background information and planned methods, without data collected in the project or conclusions based on interpretive activities of the project.

The report (1) describes the physical cha racteristics of the Neversink basin and the monitoring system, (2) presents the work elements of each of the six research topics, (3) describes the eight water: hed components to be defined through GIS, and (4) l'sts the final products (deliverables). Appendix 1 lirts the beginning and completion dates for each res ?arch 
topic, Appendix 2 describes the analytical methods used for water and soil analysis, Appendix 3 describes the quality-assurance plan for streamflow measurement, and Appendix 4 describes the computerized data-management approaches to be used.

\section{Effects of Acldic Deposition}

The Catskill region has one of the highest rates of acidic deposition in the Northeast (Stoddard and Murdoch, 1991). Both chronic and episodic acidification of surface waters in the Catskill region have been documented, and streams in the Neversink River basin are the most severely affected. Thus, atmospheric deposition is probably the primary cause of acidification of Catskill surface waters (Stoddard and Murdoch, 1991). Fish-population densities and biolngical diversity in the Neversink River are lower thar in other Catskill rivers that are less acidic, and episodic acidification has been correlated with fish mortelity (U.S. Geological Survey, unpublished data, on file in the New York District office of the U.S. Geo'ngical Survey). Nitrate $\left(\mathrm{NO}_{3}\right.$ ) concentrations as high as 128 $\mu \mathrm{mol} / \mathrm{L}$ have been measured in pristine headwater streams of the Neversink basin during periods of high rainfall and snowmelt (Murdoch and Stoddard, 1992), and, during April 1987, a plume of acidic river water

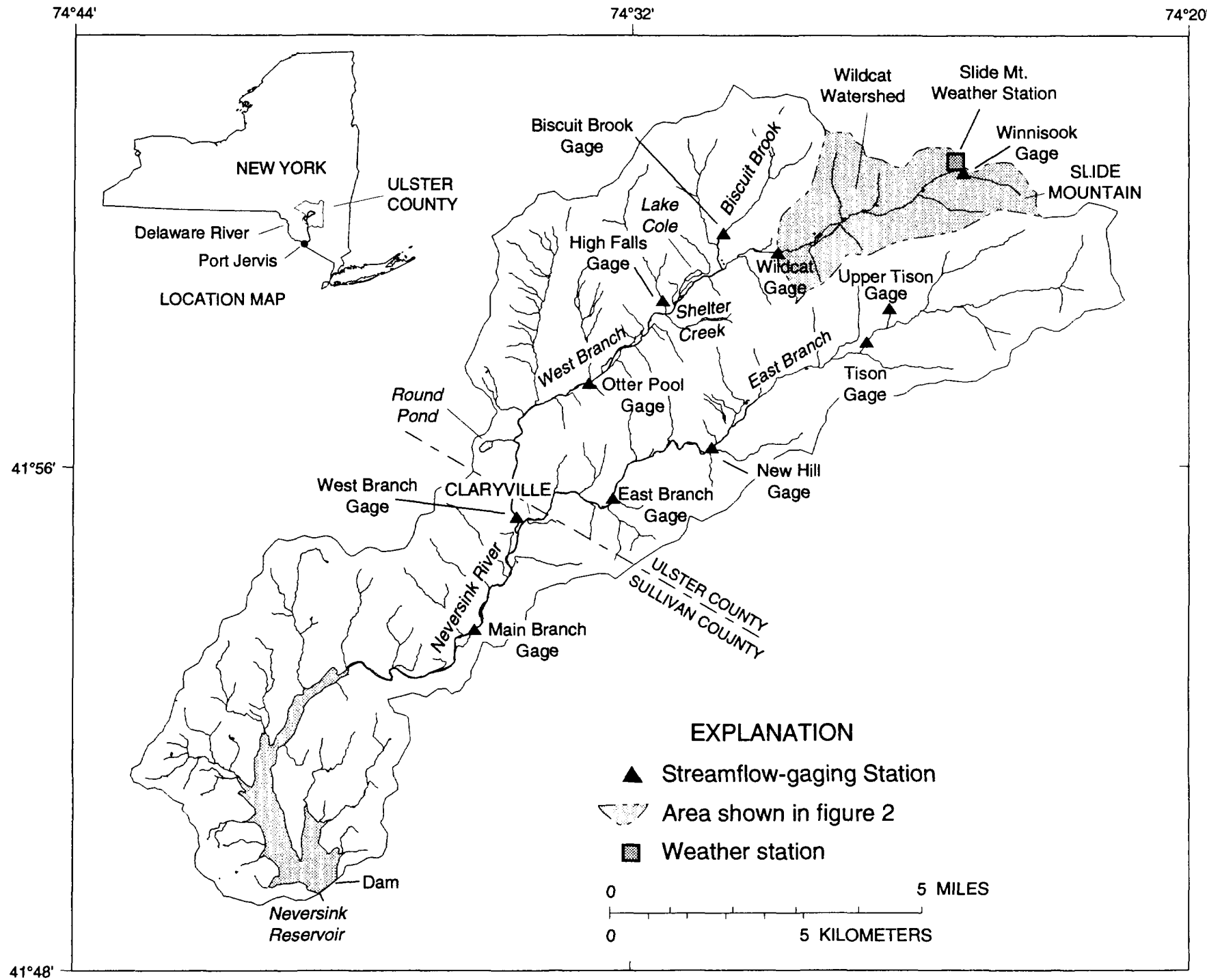

Base from U.S. Geological Survey 1:24,000 quadrangles

Figure 1. Locations of streamflow-gaging stations in the Neversink River watershed. 
with $\mathrm{NO}_{3}^{-}$concentrations greater than $100 \mu \mathrm{mol} / \mathrm{L}$ entered the Neversink Reservoir. Stream acidification has been detected throughout the Neversink basin.

Recent passage of the revised Clean Air Act is likely to result in a reduction of emissions of airborne acidic sulfur compounds in the Northeast, but how this will affect water quality in the Catskills is uncertain. Long-term monitoring at the Hubbard Brook Experimental Forest in New Hampshire has shown a decline in deposition of sulfate $\left(\mathrm{SO}_{4}{ }^{2}\right)$ over the last 2 decades without a corresponding increase in stream-water $\mathrm{pH}$ (Driscoll and others, 1989) because the stream-water concentrations of base cations also are decreasing. This decrease in base-cation concentrations in stream water could be due to a decrease in atmospheric emissions of basic particulates through improved particulate-removal technology and decreased fossil-fuel burning (Driscoll and others, 1989).

The revised Clean Air Act also is expected to decrease the atmospheric deposition of nitrogen, but the effect of such decreases on Catskill water quality is unknown. Increasing evidence suggests that forests in which nitrogen has traditionally been considered to be the growth-limiting nutrient could be approaching "nitrogen saturation" (Aber and others, 1989), a condition in which nitrogen is available in excess of plant and microbial demand (Agren and Bosatta, 1988; Skeffington and Wilson, 1988; Aber and others, 1989). Excess nitrogen in forest ecosystems can lead to increased soil nitrification and associated soil acidification according to the following stoichiometry (van Breemen and others, 1982):

$$
\mathrm{R} \cdot \mathrm{NH}_{2}+2 \mathrm{O}_{2}=\mathrm{R} \cdot \mathrm{OH}+\mathrm{NO}_{3}^{-}+\mathrm{H}^{+}
$$

Because $\mathrm{NO}_{3} \cdot$ has a low capacity for physical adsorption, it is mobile in soils and therefore can leach cations that can cause surface-water acidification. Accelerated rates of nitrification, induced by forest harvesting, have caused surface-water acidification in Northeastem hardwood forests that are similar to Catskill forests (Lawrence and others, 1987). Aber and others (1989) hypothesized that excess nitrogen could potentially lead to forest decline, and the decreases in forest productivity would in turn increase the pool of excess nitrogen and worsen the leaching of $\mathrm{NO}_{3}{ }^{-}$, which would increase surface-water acidification.

The higher growing-season concentrations of $\mathrm{NO}_{3}^{-}$ in Catskill streams than in other pristine streams in the
Northeast suggest that Catskill forests could be approaching nitrogen saturation. If so, surface-water quality could decline further as forests become decreasingly productive, despite anticipated der.reases in atmospheric nitrogen deposition. The degree to which $\mathrm{NO}_{3} \cdot$ will be leached will depend on the rates of processes such as mineralization, nitrification, plant uptake, and immobilization through microbial reactions. Other factors include the size of nitrogen pools in the current forest ecosystem, as well as stand-age structure; old trees tend to be less productive tr an young ones and therefore require less nitrogen for growth. Large areas of Catskill forestland have remained uncut for more than 75 years.

\section{Effects of Climate Change}

Several climate models have predicted a detectable increase in global temperature in the next century. One possible result would be an increased frequenc" of extreme hydrologic conditions, such as droughts and floods, that would affect mineralization and nitrification rates and thereby alter the nitrogen cycle. The effects on water quality in the Catskills could 1 ? an increased frequency and severity of surface-wa'er acidification.

Under conditions of nitrogen saturation, ertended dry periods could cause a buildup of $\mathrm{NO}_{3}{ }^{-}$in the soil and subsequent leaching in the first storm after the dry period. Surface-water acidification during this storm would be more severe than during a storm that followed shorter wetting and drying cycles. An increase in the magnitude of storms could also increase the degree of acidification that occurs during high flows by increasing the contributions from acidic source areas and decreasing soil-water residence time (Law'rence and Driscoll, 1990).

\section{Current State of Watershed Science}

Past concem over the effects of atmospheric deposition has resulted in the development of several process-based models that predict effects of various deposition scenarios on water quality (Christophersen and Wright, 1981; Cosby and others, 1985; Gherini and others, 1985). The structure of these models is typically derived from mechanisms studied in plot experiments and extrapolated to the small-watersher scale through "lumping" or statistical averaging, but the 
effects of acid precipitation in many small watersheds, including those sampled in the Catskills, show a spatial variation that is not random, but rather is systematically related to stream position on a hillslope (Johnson and others, 1981; Lawrence and others, 1986; U.S. Geological Survey, unpublished data); this variation makes spatial averaging inappropriate. Research is needed to determine how landscape features and patterns affect surface-water quality at the small-watershed scale.

Watershed-acidification models have not been extrapolated beyond the small-watershed scale, mainly because their physical basis is exceedingly complex, although some preliminary efforts to evaluate the relation between watershed scale and streamflow response have been made (Wood and others, 1988). Water-quality investigations downstream from headwater systems have focused primarily on point and nonpoint sources of pollution but have given little consideration to the role of natural watershed controls at this scale. Similarly, studies relating headwaters to higher order streams have focused primarily on how in-stream processes respond to some specific form of pollutant, rather than on natural watershed processes (Bencala and others, 1990; Lawrence and Driscoll, 1988).

\section{Project Objectlves}

This project is designed to evaluate watershed factors that control stream-water quality over spatial scales ranging from a few hectares to $240 \mathrm{~km}^{2}$ in the Neversink basin. The focus of the investigation will be on the effects of natural processes and acidic deposition, the two factors believed to most strongly affect surface-water chemistry. The project goal is the development of a conceptual model of spatial variations in stream-water quality and aquatic communities in the Neversink River basin. Because no quantitative spatial model of stream chemistry has been developed at even the small-watershed scale, construction of such a model for the entire Neversink basin is beyond the scope of this project. Quantitative relations will be established, however, that will be directly applicable to the future development of a landscape-based model that mathematically describes spatial relations of surface-water chemistry over a wide range of watershed scales.

The purpose of the conceptual model of this project is to describe spatial patterns of water chemistry and aquatic communities through a combination of survey information and quantitative relations developed in closely studied, representative types of lantscape within the basin. Information obtained from these areas will be extrapolated through a detailed, basinwide Geographic Information System (GIS) data base. The model will be designed to maximize the potential for transfer of information to Catskill watersheds outside the Neversink basin. The methods used to develop the model should also be transferable to modeling efforts for other upland watersheds in the I'vrtheast.

\section{BASIN DESCRIPTION}

The Neversink River basin is part of the Delaware River drainage. It flows generally southwestward through the Neversink Reservoir, then south to its confluence with the Delaware River near Port Jervis, N.Y. (fig. 1). The study area includes only the part of the basin above the Neversink Reservoir, an area of $240 \mathrm{~km}^{2}$.

\section{Physlography and Geology}

The Neversink River is a clear, energet: $?$ mountain river whose valley bottom nowhere exceeds a width of $0.75 \mathrm{~km}$. Upstream from the town of Clar rville, $9 \mathrm{~km}$ above the reservoir (fig. 1), the river divides into an east and a west branch with watersheds of nearly equal in area. Both branches originate near the summit of Slide Mountain $(1,274 \mathrm{~m})$, the highest point in the Catskill Mountains. Hillslopes in the head vaters, and slopes and tributary valleys further downvalley, are steep. The West Branch valley widens just upstream from the junction with Biscuit Brook, and the East Branch valley widens similarly just downstream from the Tison gage. Both branches have discontinuous flood plains from where they widen until they join in Claryville.

Underlying the Neversink basin are flat-lying sedimentary bedrock of Devonian age, overla $n$ by till deposits and alluvium (Rich, 1934; Way, 1972). The Devonian rocks were formed from sediment eroded from former mountains to the east and were deposited as part of a massive delta several thousand meters thick. The Catskill delta has since been uplifted and now stands at a higher elevation than the surrounding land. The bedrock of the Catskill Mountains in the region of the Neversink basin is about 60 percent 
sandstone and conglomerate and 40 percent shale and siltstone. Quartz is the dominant bedrock mineral, and muscovite and amphibole are common accessory minerals (Ethridge, 1977). Calcite and hematite are the principal interstitial cement materials in the bedrock but are generally present in only minor amounts.

The bedrock of the Neversink basin is overlain by a veneer of till derived primarily from the most recent glaciation, which ended about 14,000 years ago. The till is thicker in stream valleys than on the steep, upper slopes. Some of the till has been reworked and deposited as alluvium adjacent to stream channels on the valley floors. In the lower East Branch Neversink valley, Rich (1934) mapped till that predates the most recent glaciation.

\section{Solls}

Most of the soils within the Neversink basin are classified as inceptisols in the Amot-Oquaga-Lackawanna association (Tomes, 1979). Some spodosols underlie coniferous stands. These soils vary in thickness and are excessively to moderately well drained, predominantly steep, and medium textured on uplands. A distinguishing characteristic of these soils is the presence of a dense, cementlike fragipan beginning at a depth of $1 / 2 \mathrm{~m}$ to $1 \mathrm{~m}$ below the surface. Fragipans are found only where the till is at least $1 \mathrm{~m}$ thick. A fragipan slows the infiltration of water and can result in perched water during and after rainstorms. Rich (1934) believed the fragipan formed beneath the glacier as it deposited and compacted its load, but Kudish (1979) dismissed this idea because fragipans have been found outside glaciated regions and attributed their formation to the presence of adequate silt and clay to cement large soil fragments together.

The soils are generally acidic; Kudish (1979) obtained a mean $\mathrm{pH}$ of 5.0 from 150 Catskill mineralsoil samples. The $\mathrm{pH}$ distribution of the soils has no systematic spatial or elevational variability. Soilhumus $\mathrm{pH}$ is related to the type of vegetation present; Kudish (1979) found the mean $\mathrm{pH}$ of coniferous-stand humus from the same 150 sampling locations to be 4.3, and that of deciduous-stand humus to be 4.6. The acidity of soils is a reflection of the base-poor local bedrock. Although some of the till was transported from the north, Parker and others (1964) estimated that at least 90 percent of the till in the Catskills is derived from local rock and sediment.

\section{History of Vegetation and Land Use}

Vegetation in the Neversink basin is prims rily northern hardwood forest in which three tree s xecies dominate: American Beech (Fagus grandifolia), Sugar Maple (Acer saccharum), and Yellow Birch (Fetula alleghaniensis). Red Spruce (Picea rubens) and Balsam Fir (Abies balsamea) are the dominant species at elevations above $1,000 \mathrm{~m}$ (Kudish, 1979). S ands of hemlock (Tsuga canadiensis) grow on poorly drained soils. Various herbs, ferns, club mosses, grasses, and wildflowers grow as ground cover beneath the forest canopy; the distribution of these plants is primarily dependent on the $\mathrm{pH}$ of the humus layer. (A complete listing of Catskill ground-cover species is given in Kudish, 1979.)

After glaciation ended, the Catskills were first invaded by alpine vegetation, followed by boreal forest (Kudish, 1979). Later, northem hardwoods ar I hemlock propagated northward into the region and ascended mountain slopes to as high as the minimum till-thickness tolerance of each species would allow. Evidence from pollen in peat bogs indicates that northem hardwoods have been established at high el svations in the Catskills for at least several thousand years (Kudish, 1979).

Man has had a significant effect on the forests of the Catskill Mountains since the mid-1700's, when logs were cut for ship masts and floated down "tream. In the early 1800 's, an attempt to make the Neversink River navigable for $\log$ rafts ended in failure. Leather tanning became the principal Catskill industry' in the 1800 's; as a result, hemlock trees were felled, stripped of their bark, and left to rot while the bark wa? transported to nearby streamside tanneries. Many sawmills cut pine and, later, hardwoods into lumber thrnughout the Catskills during this time.

By the late 19th century, most of the hemlock and pine had been cut, but the forests above $850 \mathrm{~m}$ remained mostly undisturbed and remain uncu. to date. The upper watersheds of the Catskills were de ${ }^{\text {rignated }}$ a State preserve in 1870 .

The Neversink basin is predominantly forested (CLEAR, 1988), although limited cutting cont'nues. A small amount of the open meadow in the river valley is used for horse grazing. The basin contains or'y a few farms and has a population of less than 1,300.

The greatest physical change in the Neversink basin during the 20 th century was the completion of the 
Neversink Dam (fig. 1) in 1950; the reservoir flooded about $10 \mathrm{~km}$ of the river valley. The only other significant land-use disturbance in the basin is the application of salt to roads that parallel the river. The effect of road salt on water quality in the Neversink River is unknown.

A few small manmade ponds, the largest of which are Round Pond and Lake Cole (fig. 1), are used for recreation in the summer. Wetlands identified by the U.S. Fish and Wildlife Service wetland inventory mapping constitute less than 5 percent of the total basin area.

\section{Climate}

The climate of the Neversink basin is classified as humid continental, with cold winters and moderately warm summers. The range in elevation within the watershed results in distinct spatial variation in temperature and precipitation. The mean annual temperature at the Slide Mountain weather station $(808 \mathrm{~m})$ is $4.3^{\circ} \mathrm{C}$, and at the summit $(1,274 \mathrm{~m})$ has been estimated to be $3.3^{\circ} \mathrm{C}$ (Kudish, 1979). At Liberty, just west of the basin at an elevation similar to that of the reservoir (472 $\mathrm{m}$ ), mean annual temperature is $7.2^{\circ} \mathrm{C}$ (National Oceanic and Atmospheric Administration, 1990). This temperature difference within the watershed is fairly constant through the year.

Mean annual precipitation in the Neversink River basin is among the highest in the Northeast. The summit of Slide Mountain (fig. 1) receives more than 175 $\mathrm{cm} / \mathrm{yr}, 22.7$ percent of which falls as snow (Iorio, 1972). During 1950-85, the National Weather Service station at Slide Mountain received a mean of 157 $\mathrm{cm} / \mathrm{yr}$, and the weather station at Claryville received $140 \mathrm{~cm} / \mathrm{yr}$ (National Oceanic and Atmospheric Administration, 1990). The large amounts of precipitation are caused by a combination of Atlantic coastal storms and an orographic effect from storms approaching from the southwest. Precipitation amounts are fairly uniformly distributed throughout the year.

Annual precipitation is closely correlated with annual runoff; the Neversink River averages more than $75 \mathrm{~cm} / \mathrm{yr}$, one of the highest runoff rates in the Northeast (Gebert and others, 1985). Cyclic accumulation and melting of the snowpack occurs throughout the winter, and snow depth ranges from 0 to $100 \mathrm{~cm}$. Upper soil layers freeze during periods of little or no snow cover.

\section{CATSKILL DATA BASES}

The data bases that have been developed for streams and precipitation in the central Cat ${ }^{-k i l l ~ r e g i o n ~}$ provide a basis for comparison with and interpretation of data collected during the project. These data bases can be categorized as (1) long-term precipitation, streamflow, and stream-chemistry data, wrich will be used primarily for trend analysis, and (2) short-term streamflow and chemistry data, which will be used for specific research objectives.

\section{Precipitation}

The National Weather Service has coll'cted precipitation-volume and air-temperature data since 1948 at Slide Mountain and for shorter periods at the confluence of the West and East branches of the Neversink River and the south end of the Neversink F eservoir as part of their national monitoring program. These data are published in the National Weather Service's annual summaries for New York State. In addition, the NYCDEP has been measuring rainfall at several stations in the watersheds of each reservoir since the reservoirs were built. The USGS has been collecting rainfall-volume data and weekly wet-deposition data at Biscuit Brook (fig. 1) as part of the National Trends Network (NTN) since 1983 (U.S. Geological Survey, unpublished data) and, during 1985-87, the. USGS operated an 18-station precipitation-data network for volume and selected stormwater constituents at elevations ranging from 1,274 to $183 \mathrm{~m}$ (U.S. Geological Survey, data available in the New York District Office). Preliminary analyses of data from these networks indicate that precipitation increases as elevation increases, and that precipitation chemistry has no clearly defined relation to elevation.

\section{Long-Term Stream Monitoring}

Several data bases have been compiled from longterm monitoring of stream discharge and water quality in the Catskill region. The longest of these data bases was collected by the NYCDEP to monitor waters entering the city reservoir system (table 1 ). Three of these sites (Neversink River at Claryville, Esopus Creek at Coldbrook, and Rondout Creek at Lowes Comers) also have USGS streamflow-gaging stations at which data have been collected since the NYCDEP program began (in 1951, 1931, and 1937, respectively). The USGS has collected water-quality data seasonally on the 
Esopus Creek at Shandaken since 1967 as part of its Hydrologic Benchmark Program and maintains several other stream gages throughout the Catskill region. These data are published in the USGS annual waterdata reports.

The USGS has been monitoring stream-water quality at Biscuit Brook, a tributary to the West Branch Neversink River (fig. 1), since 1983 (Stoddard and Murdoch, 1991) as part of its Small Watershed Program, which includes continuous monitoring of discharge and weekly sampling of water quality. Seven other streams have been sampled and their discharge measured 10 to 12 times per year since 1983 as part of the U.S. Environmental Protection Agency
Long-Term Monitoring (LTM) project.

Analyses of these long-term records are reprted in Murdoch and Stoddard (1992, 1993), Stoddarc and Murdoch (1991), and Stoddard (1991). The data indicate trends of decreasing sulfate concentration and increasing nitrate concentrations in several streams, but the effects on $\mathrm{pH}$ and acid-neutralizing capacity' (ANC) are unknown (Murdoch and Stoddard, 1993; Stoddard, 1991). Streams in the southem Catskills gene ally have low ANC (less than $200 \mu \mathrm{eq} / \mathrm{L}$ ), whereas streams in the northern Catskills have moderate ANC (1)ss than $300 \mu \mathrm{eq} / \mathrm{L}$ ). The Neversink River basin conta' $n$ s the most acidic headwater streams of those sampled in the Catskill region.

Table 1.-Location, drainage area, and period of record at the long-term monitoring sites in the

Catskill Mountain region, N.Y.

$\left[\mathrm{km}^{2}=\right.$ square kilometers]

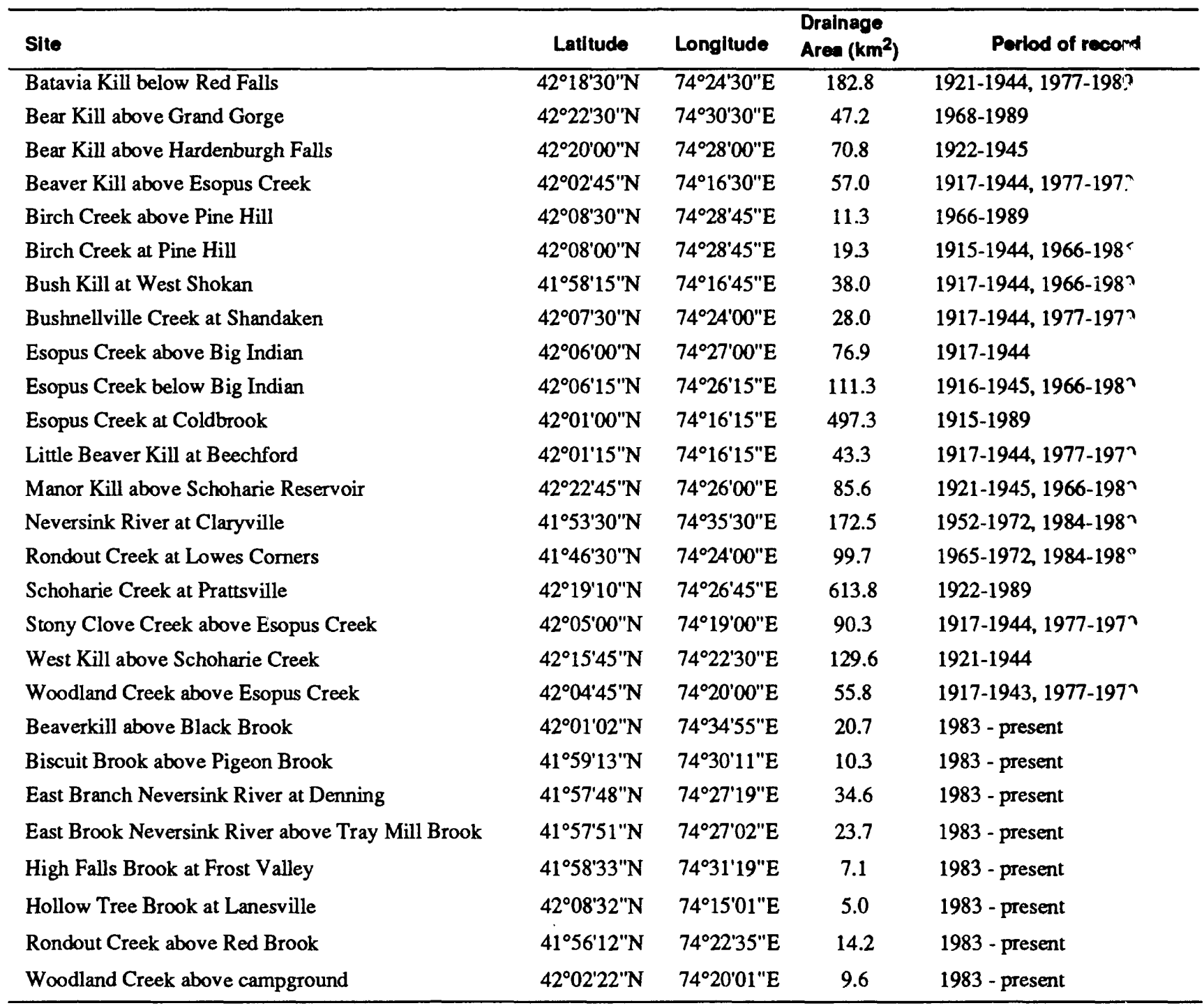




\section{Short-Term Stream Monltoring}

Several short-term data bases of stream-water quality in the Catskill region have also been developed. The USGS conducted a seasonal water-quality-sampling program during 1973-75 on the Neversink River in Claryville in which samples were analyzed for $\mathrm{pH}$, alkalinity, and major cation and anion concentrations. These data are included in the annual USGS data reports for the period (U.S. Geological Survey, 1974, 1975, 1976).

Regional sampling of stream-water quality was done seasonally during 1985-87 at 66 stream stations as part of a cooperative research program with the NYCDEP (U.S. Geological Survey, unpublished data, 1985-87). The seven LTM streams and Biscuit Brook were part of this network, which included the main river entering each of the 5 New York City reservoirs and 6 to 11 tributaries to each of those rivers. In all, 23 stations were established on the Neversink River upstream from the USGS gage near Claryville and were sampled during high discharge in the spring of 1987 (U.S. Geological Survey, unpublished data). Data from this network indicate that stream ANC concentrations decrease from north to south across the Catskills, paralleling decreases in calcium concentrations, whereas concentrations of other constituents were relatively similar across the region. The Neversink River had the lowest recorded ANC and calcium concentrations in the region (Murdoch and Stoddard, 1993).

A major focus of the research projects from 1983 to the present has been episodic acidification-the rapid increases in acidity that occur in streams during rainstorms and snowmelt. Frequent sampling of stream water during rainstorms was done at Biscuit Brook during 1984-85 as part of a USEPA-funded program to study episodic acidification in several regions of the eastern United States (Murdoch and others, 1990). Synoptic surveys of stream chemistry during peak discharge in the spring and fall were done during 1986 and 1987 along the length of the Neversink River above the reservoir as part of the cooperative research program with the NYCDEP (U.S. Geological Survey, unpublished data). During 1988-89, the USEPA again funded episodic acidification research through the Episodic Response Project (ERP), which was designed to define (1) the magnitude and frequency of episodic acidification in headwater streams, (2) the processes that control acidification, and (3) the effect of episodes on fish and invertebrate populations. Results of these studies have shown that episodic acidification in Catskill Mountain streams can cause mortality and decreased population densities of fish and invertebrates (Murdoch and other:, 1991).

\section{RESEARCH APPROACH}

This project contains six topics related to terrestrial and aquatic controls of stream chemistry. The datacollection program for the six topics is projocted to last 5 years (1991-95). Project completion is anticipated at the end of the 5th year (1995), and additional support will be sought to continue flow measurements and water sampling at selected sites and to extend nitrogenbudget monitoring.

Work elements have been designed to address specific questions relevant to each of the six topics (designated A through F). Because many of the activities of this project will be original research, the specific approaches to be used in each work element are designed to test particular hypotheses, and the information obtained through hypothesis testing will be used to build the conceptual spatial model. All of the spatial interpretation will use a detailed GIS data base that will represent the entire Neversink basin. (Development of the GIS data base is described in a later sertion, "Geographic Information System [GIS] Suppor. Activities.") Unanticipated results could require some modification of the approaches described 1 ?rein, but all modifications will be made in keeping with the overall project goal of developing the conceptual spatial model of Neversink stream-water quality.

\section{Topic A. Small (First-Order) Watersheds}

Many first-order (headwater) streams in the Neversink basin have elevation-related gradients in stream chemistry (hereafter referred to as elevational gradients). In these streams, pH tends to be lowest in the uppermost reaches and to increase steadily downstream. This pattem is typical of North American upland watersheds that overlie noncalcarenus bedrock and till (Powers, 1929; Johnson and others, 1981; Lawrence and others, 1986; Driscoll and others, 1988). Increases in stream-water $\mathrm{pH}$ with decreasing elevation have been attributed to (1) downstream increases in soil-water residence time (Johnson and others, 1981) and (2) hillslope gradients in soil chemistr' ${ }^{\prime}$, known as soil catenas (Lawrence and others, 1986). Specific 
data relating elevational gradients in stream chemistry to spatial patterns of biogeochemical or hydrologic processes within watersheds have not been collected, however.

To quantify the spatial effects of hillslope processes on first-order-stream chemistry, three work elements are designed to evaluate the relative importance of subsurface-water residence time and soil catenas. This information will be used to develop a spatial model for first-order watersheds in the Neversink basin. Winnisook watershed (fig. 2) will be used for most of the small-watershed investigations because its topography and stream chemistry are typical of highelevation first-order watersheds within the Neversink basin and because this basin is more accessible than most of the other first-order watersheds.

\section{Work Element 1. Subsurface-Water Residence Time}

Hypothesis 1.-Elevational gradients in streamwater chemistry among headwater streams are a function of subsurface-water residence time.
Hypothesis 2.-Subsurface-water residenc? time in first-order watersheds can be inferred from hillslope position, topography, and hydraulic properties of the soil.

Objective.-To develop an empirical relat: on between spatial variations in stream-water che nistry and indices of subsurface-water residence time that can be computed from a GIS data base.

Approach.-Stream-water-sampling sites will be selected such that they divide Winnisook Watershed into eight drainage areas of about equal size (f०o. 2). This watershed will be instrumented with a permanent stream gage and throughfall collectors along an elevational gradient. All major seeps along the stream reach from the base of the watershed to the highest sampling site will be identified.

Seepage samples will be collected monthly during nonwinter seasons for 2 years at eight of the srepage sites. Water temperatures will be measured biweekly at all seeps to infer subsurface-water residence time from the temperature fluctuations. Flow at each seep at the time of collection will also be measured. Seep-water

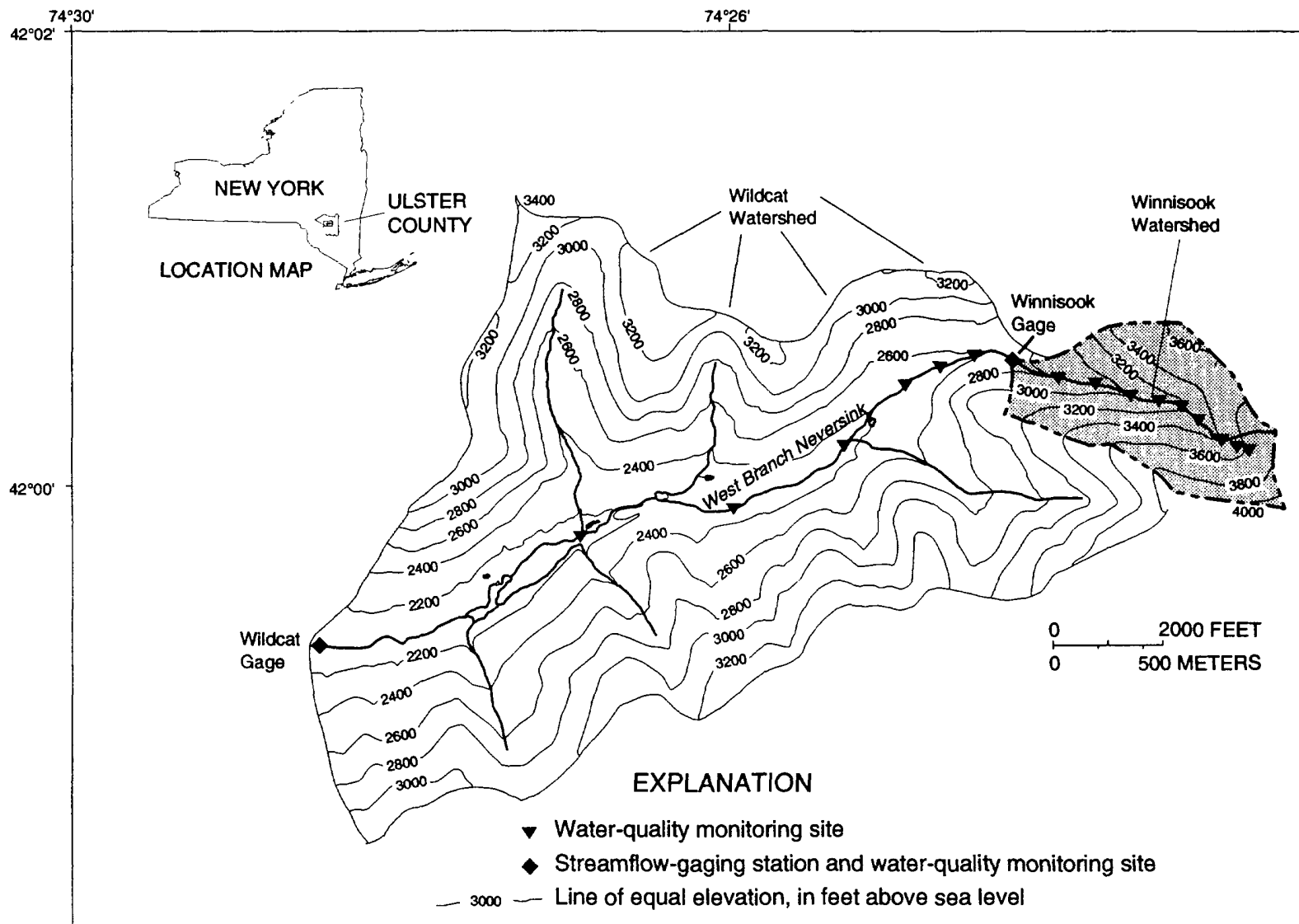

Base from U.S. Geological Survey $1: 24,000$ quadrangles

Figure 2. Locations of streamflow-gaging stations in Wildcat and Winnisook Watersheds. (Location is shown in fig. 1.) 
and stream-water samples will be analyzed for all major solutes. Selected precipitation, seepage, and stream-water samples will also be analyzed for ${ }^{18} \mathrm{O}$ concentrations to provide additional information on subsurface-water residence time.

Estimates of subsurface-water residence time will also be computed from topographic data and soil hydraulic data through components of the hydrologic model TOPMODEL (Wolock and others, 1990). Topographic contour data will be interpolated onto a regular 30-m grid through ARC/INFO and processed with FORTRAN programs to derive the spatial distribution of the topographic index $\ln (a / \tan B)$, where $a$ is the area upslope from a point that drains down to that point, and $\tan B$ is the slope. Soil hydraulic data, specifically the saturated hydraulic conductivity $(K)$, depth to bedrock $(b)$, and porosity $(n)$ will be derived from the soil-survey ARC/INFO data. An index of subsurface-water residence time (Wolock and others, 1989) will be computed as $(b n)^{L}$, where $L$ is the mean of the $\ln (a / K b \tan B)$ spatial distribution for the area upslope from a point of interest. The residence-time index will be computed for selected locations in the stream at which water-quality data are being collected to determine whether the index of residence time is a reliable predictor of stream chemistry.

The resulting information will be used to evaluate subsurface-water residence time as a possible control of stream-water chemistry. Temperature fluctuations of seepage, the slope of flow-duration curves, and timing of seepage-flow and seepage-chemistry responses to storms will provide indications of subsurface-water residence time. Digital elevation data available in the GIS data base also will be used to evaluate hillslope position and topography as possible indices of subsurface-water residence time. These indices will be developed as polygon coverages. Empirical relations will then be developed that describe the elevational gradient of stream-water chemistry in this watershed from indices of subsurface-water residence time.

Stream-water samples will be collected biweekly for 2 years and monthly in the 3rd year, and analyzed for all major solutes. Flow will be measured periodically at each of the stream-water-sampling sites to establish a predictive relation between flow at the gage and flow at each of these sites. Sampling over a 3-year period will provide a sufficiently large data base to evaluate relations between concentration and discharge. This information will be used to develop algorithms that describe spatial variations of stream chemistry for specified ranges of flow if on: algorithm is not applicable to all flows.

\section{Work Element 2. Hillslope Gradients of Soil Chemistry}

Hypothesis 1.-Consistent elevational gradients in stream-water chemistry in first-order streams are a function of elevational gradients of soil chamistry, known as soil catenas.

Hypothesis 2.-Spatial patterns of soil chemistry in first-order watersheds can be inferred frc $m$ hillslope position, topography, and soils information available from Soil Conservation Service maps.

Objective.-To develop an empirical rlation between stream-water chemistry and hillslope-soilchemistry indices available in the GIS dat $z$ base.

Approach.-Comprehensive soil samp'ing will be done in Winnisook Watershed to investigat ? the role of hillslope gradients in soil chemistry in determining low-order-stream chemistry. Soil-samplin? locations will be selected to encompass the range of slope, aspect, and hillslope positions within the watershed. Samples will be collected from the $\mathrm{Oa}$ and Bs horizons along a series of transects perpendicular to the stream; this series will extend from the base of the watershed to the highest elevations. All sampling locations will be recorded by field surveying. Soil chemistry will then be evaluated in relation to hillslope positior. slope, and aspect through GIS software. Soil samples will be analyzed for $\mathrm{pH}$, exchangeable bases, exchanc:able acidity, total carbon, total nitrogen, $\mathrm{KCl}$-exchangeable $\mathrm{Al}$, and water- and $\mathrm{NaH}_{2} \mathrm{PO}_{4}$-extractable $\mathrm{SO}_{4}{ }_{4}^{2}$.

Spatial patterns of soil chemistry in forst soils are often difficult to detect because the chemistry typically varies widely over a scale of a few meters c - less (Huntington and others, 1988); therefore, a second approach will be used in which nylon-mesh bags filled with mineral soil of uniform composition will be bu ied in association with the soil pits excavated for the soil sampling. The soil to be used for this expe riment will have an initial base saturation greater than 15 percent. The soil will be homogenized, then placed in the bags and inserted in the soil profile. Initial chemistry of the soil will be determined, then, after 1 year, the bags will be excavated and the soil reanalyzed to evaluate the effect of hillslope position. This approach has been used successfully in plot-manipulation studies (David and others, 1990). 
The two approaches for identifying spatial patterns in soil chemistry will be evaluated to determine whether stream-water chemistry can be viewed as a function of hillslope variations in soil chemistry. Information available in the GIS data base, including hillslope position, topography, vegetation, and data from Soil Conservation Service soil survey maps, will then be evaluated as possible indices of the spatial patterns of stream chemistry. As in Work Element 1, empirical relations for Winnisook Watershed will be developed to relate spatial variations of stream-water chemistry to soil-chemistry indices available in the GIS data base.

\section{Work Element 3. Extrapolation of Relations to Other First-Order Watersheds}

Hypothesis.-Empirical relations between streamwater chemistry and indices of (1) subsurface-water residence time, and (2) hillslope patterns of soil chemistry defined in Winnisook Watershed, are applicable to other first-order watersheds in the Neversink basin.

Objective.-To test the generality of spatial relations that were developed to describe stream-water chemistry in Winnisook Watershed.

Approach.-Stream-water samples will be collected along elevational gradients of about 15 firstorder streams and analyzed for all major solutes. From this survey, four streams will be selected that collectively include the range of watershed characteristics that are representative of first-order watersheds within the Neversink basin. A continuous streamflow gage will be installed in one of these streams, which will be in an area of the Neversink basin remote from Winnisook Watershed.

Stream-water-sampling sites within the four watersheds will be positioned to divide the watersheds into about eight subbasins of about equal drainage area. The subbasin streams will be sampled on the same day at low, medium, and high flows, and each sample will be analyzed for all major solutes.

Empirical relations developed for Winnisook Watershed will then be applied to the data from the additional four watersheds, through indices computed from the GIS data base, to test their applicability. These relations will be evaluated over a range of flows in each of the watersheds. Empirical relations to predict spatial patterns of stream chemistry will be refined through additional information obtained from the four watersheds. This procedure will include an assessment of error propogation to account fo- unexplained variation in the developed relations. The refined empirical relations will then be used in conjunction with the GIS data base to predict the streamwater chemistry of 20 first-order streams at a point just upstream from the confluence with another steeam. These 20 locations will be sampled three times over a wide range of flows to evaluate the accuracy of the predictions.

\section{Topic B. Intermediate and Large Watersheds}

The elevational gradients in stream-water chemistry that have been identified in headwater streams within the Neversink basin extend downstream; water entering the Neversink Reservoir tends to have higher $\mathrm{pH}$ and ionic strength (with a few isolated exceptions) than water at all upstream sites within the basin. Episodic depressions in $\mathrm{pH}$ associated with large streamflows also extend downstream to the reservoir.

Little research has been done on natural watershed processes that affect stream-water chemistry in medium and large watersheds; therefore, the applicability of information from small-watershed research to larger watersheds is unknown. Expanding the scale at which watershed research is conducted lies within the newly evolving discipline of landscape ecology, which has been integrated into land-use planning in Europe for the past decade (Turner and Gardner, 1990). Traditionally, watershed science has relied on either mechanistic investigations in plots, or the "black box" approach, which assumes an entire watershec' to be a discrete, homogeneous ecosystem. Neither a pproach allows extrapolation of small-watershed data to larger areas, whereas landscape ecology emphasizes patterns and processes within areas of differing sizes.

Longitudinal (downstream) gradients of stream chemistry will be evaluated in intermediate and large watersheds to determine whether the spatial variations from headwaters to the reservoir can be interyreted as part of a continuum of the same landscape or reflect a series of discrete landscapes with processes that vary according to local internal patterns. The relation between watershed size and temporal variations in the chemistry of dissolved and suspended solids in intermediate and large watersheds will also be evaluated. 


\section{Work Element 1. Spatial Controls in Intermediate and Large Watersheds}

Hypothesis 1.-The chemistry of stream water at any point in the basin is a function of the distance from this point to the start of flow in the tributary that is farthest upstream.

Hypothesis 2.-The chemistry of stream water at any point in the basin can be viewed as a function of drainage area.

Hypothesis 3.- The chemistry of stream water at any point in the basin is a function of subsurface-water residence time, which in tum is a function of topography and hydraulic characteristics of the soil.

Objective.-To evaluate the relative importance of landscape positions and drainage area in defining spatial patterns of stream chemistry in watersheds drained by streams that are second order or larger.

Approach.-To evaluate controls of stream chemistry in medium-sized watersheds, a streamflowgaging station will be installed about $5 \mathrm{~km}$ downstream from the Winnisook gaging station (Wildcat gage, fig. 2), and 10 sampling sites will be installed between the two gaging stations. Samples will be collected at these sites biweekly for the first 2 years of the project and monthly for the 3rd year, and analyzed for all major solutes. Empirical spatial relations developed for first-order watersheds will then be extrapolated over the reach of 10 sites to determine whether the scale of processes that control spatial patterns of stream chemistry in the headwaters are of equal importance in larger systems.

Water samples and flow measurements will be taken at the five major tributaries to this reach on three separate dates to determine their effect on streamchemistry gradients. The effect of the tributaries will be quantified through mass-balance calculations and chemical equilibrium modeling through ALCHEMI (Schecher and Driscoll, 1987). The streams of two other intermediate-sized watersheds (Biscuit Brook and Tison Brook, fig. 1, fig. 2) will be longitudinally sampled above the present gages at high, intermediate, and low flows to determine whether longitudinal trends of stream chemistry are consistent among the three watersheds. The GIS data base will be used to help evaluate these trends in relation to watershed characteristics, which include stream order, position on the hillslope, topography, aspect, drainage area, vegetation, and soils.
Four additional streamflow-gaging stztions (Otter pool, West Branch Claryville, East Brancl Claryville, and New Hill Bridge, fig. 1) will be installed at locations lower in the drainage than Wildcat gage to evaluate longitudinal gradients of stream chemistry at an increased scale on the East and West Branches of the Neversink River. The present gages on th: East Branch and below the confluence of the Erst and West Branches of the Neversink River (Main Branch; fig. 1) will be included in this analysis. In addition to continuous flow monitoring at these gages, water samples will be collected biweekly for complete cl amical analysis. On three occasions, flow at all major tributaries to the East and West Branches and 1 low the confluence of the East and West Branches of the Neversink River will be measured or estimated from a hydraulic model. Stream-water samples w'ill be collected concurrently with flow measurements at these locations for analysis for major solutes. This information will be used for analysis of longitudinal gradients and effects of tributaries in the same manner as for the intermediate-scale watersheds.

\section{Work Element 2. Effect of Watershed rize on Temporal Variations in Stream Chemistry}

Hypothesis 1.-Temporal variations in stream chemistry are attenuated as drainage area increases.

Hypothesis 2.-Temporal variations in stream chemistry are directly related to the surfac--runoff component of streamflow during high flow's.

Objective.-To determine the magnitude of temporal variations in water quality for the small, medium, and large watersheds within the Neversink basin.

Approach.-High-frequency stage-activated stream-water sampling will be done at five gaging stations on the West Branch Neversink River for 1 month during one spring and one fall. Each sample will be analyzed for major solutes. The remonse of stream chemistry to changes in flow at each sampling site will be compared with the response at the other site to establish a relation between temporal variations in streamflow and watershed size. The model of Johnson and others (1969) will be used to quantify concentration-to-discharge relations. Continuous $\mathrm{p}^{x}$ monitors will be installed at the Winnisook and Main Branch gaging stations (fig. 1) to provide additional information on short-term changes in stream cherr istry that might not be directly related to changes in flow. 
A transfer function (time series) model will be fitted to the flow and concentration data to quantify the strength of the relation between flow and concentration. An index of the surface-runoff component in streamflow will be derived from the GIS topography and soil data bases. The observed strength of the flowto-concentration relation will be compared with a flowpath index to determine whether spatial patterns in the temporal variation in stream chemistry can be attributed to spatial patterns in flow paths.

In addition to the chemical analysis of solutes, samples collected at the Main Branch site by automatic water sampler will be analyzed for total nitrogen, total phosphorus, and total suspended-solids concentrations. Automatic stage-activated water sampling will be done at this site throughout the study, as will periodic sampling for suspended solids during base flow.

Results of stream-water sampling will be maintained in files directly related to the GIS data base. This information will be used in conjunction with flow data to define the relation between seasonal variations in stream chemistry and watershed size. The GIS data base will be used to integrate the magnitude of the chemical changes over time with their geographic distribution.

\section{Topic C. Landscape Controls of Stream Chemistry}

The null hypothesis of the work elements of topics A and B (described above) is that subbasin position along a stream is not the major determinant of soil and stream-water characteristics. In watersheds with significant human activity, for example, point-source chemical contributions can significantly alter any natural downstream pattern of water-quality evolution. Similarly, in relatively undisturbed systems such as the Neversink, certain local soil or surface-water characteristics can cause irregular patterns in water quality along an elevation gradient. Studies have shown, for example, that changes in vegetation can significantly affect water quality along the length of a stream, regardless of elevation (Lawrence and others, 1986). An assessment of the relation between water quality in headwater streams and that in the larger rivers downstream therefore requires information on how nonsystematic changes in landscape can affect stream-water quality.
Chemical changes in water as it moves through the soil have been studied extensively, but the eff 3 ct of these changes on stream chemistry remains difficult to quantify (Lawrence and Fernandez, 1991; Bishop and others, 1990; David and Driscoll, 1984). Measurement networks with the instrumentation necessary to monitor water flux through a particular zone of a vatershed would be prohibitively expensive, and the disturbance inherent in the installation of such numerous instruments would probably disrupt the natural flow of water. Models that mathematically link hydrologic characteristics of basins with chemical characteristics of stream waters have had some success in predicting both the discharges and the concentrations of selected constituents at the outlet of small watersheds (Hooper and others, 1990; Gherini and others, 1985; Christophersen and Wright, 1981). Many of these models include parameters that cannot be uniquely identified by the calibration data, however, and therefore have limited utility outside the range of conditions under which they were calibrated (Hooper and others, 1990).

The "End-Member Mixing Analysis," or EMMA model designed by Christophersen and others (1990), relates "end member" concentrations (observed chemical concentrations in water from specified sources) to stream-water chemistry without use of soil-v'ater flux rates. When plotted on a graph, end-member concentrations delineate the range of stream chemistry that can result from the conservative mixing of end members. End members that affect stream-water quality might include water from the organic horizon of the soil, the mineral horizon of the soil, or deep aquifers. Stream concentrations that plot outside this area indicate either that not all end members have been accounted for, or that mixing is not conservative. Through this approach, the relative contribution of each end member to stream-water concentrations can be estimated, and this information can, in turn, be used to indicate which landscape processes control streamwater chemistry.

This approach can typically be applied ti only a few locations, however, because installation of collection equipment is costly, and the question of whether the results are representative of the specific type of landscape would still be unanswered. To relate such "site-specific" information to chemical procerses in the Neversink watershed as a whole will require a regional survey of the chemical conditions in several areas for each type of landscape. The survey will inc'ude 
stream-discharge measurement and water-quality sampling at the upstream and downstream end of stream reaches within selected types of landscape (such as several hemlock groves, wet-soil zones near streams, etc.). The results will be used to compute the chemical inputs to and outputs from each type of landscape, and the average values will be compared with streamchemistry data from other types of landscapes and from selected stream-monitoring stations on the Neversink River to predict stream chemistry from the landscape chemistry.

The approach to this part of the research program will have two elements. The first will entail (1) reconnaissance of surface waters entering and leaving areas of specific types of landscape to identify which types of landscape have the greatest effect on stream chemistry; (2) mapping of three to five different types of landscape within the watershed to obtain estimates of the spatial distribution, number of areas of each type, and percentage of watershed area occupied each type;and (3) regional surveys of landscape effect on water quality. The EMMA approach, which treats each type of landscape as an end member, will then be used to determine the relative effect of each type of landscape on stream chemistry and predict water quality at selected gaging stations in the Neversink River. The second element will include sampling of surface water, soil water, seep water, and atmospheric deposition at stations representing each type of landscape to identify key hydrologic factors as end members for predicting changes in stream-water quality within those landscapes.

\section{Work Element 1. Identifying the Effect of Land- scapes on Neversink River Water Quality}

Hypothesis.-Specific types of landscape that cause local, nonsystematic changes in stream-water chemistry within a watershed can be identified, and the distribution of these areas (subcatchments) can be used to predict longitudinal changes in stream chemistry in the Neversink River.

Objective.-To (1) evaluate relations between specific types of landscape and general spatial variations in stream-water chemistry, and (2) map the spatial distribution and locations of these types of landscape for the spatial model.

Approach.-To identify the major types of landscape in the basin through (1) a field reconnaissance,
(2) a sampling program to define flow and(or) chem istry of stream water entering and leaving representative landscapes, and (3) a mapping program to delineate these landscape areas so that information can be incorporated into the GIS data base. The data from each type of landscape will then be averaged for use as end members for predicting stream chemistry.

In the reconnaissance phase of the study, stream water will be sampled throughout the Neversink basin to identify areas in which stream chemistr:' changes over short distances. These areas could renresent (1) major changes in slope or type of soil relative to upstream areas, (2) standing water in lakes, ponds, or wetlands, or changes in the number or protuctivity of seeps, and (3) changes in forest vegetatior. Detailed sampling of stream and seep water will then be conducted in areas where chemical transitions occur. The resulting data will be used to select specific types of landscape for study of their effect on strean-water quality. Detailed sampling of chemical-transition zones will result in longitudinal profiles of streamwater chemistry, temperature, and, in som: cases, discharge. Topography of the subcatchments will be characterized, and types of forest stands will $b$ : identified.

Once the key types of landscape that affect surfacewater chemistry in the Neversink watershe 7 have been identified, a stream-sampling program will be established for each, and stream chemistry and discharge will be measured four times over a wide range at the upper and lower boundaries of each area. Several locations above and below each landscape area will be sampled during each survey. Samples will be a composite of depth-integrated samples collected across the channel to ensure sampling of all water entering that stream segment from each landscape area. From this data set, instantaneous-load calculations (concentration $\mathrm{x}$ discharge) will be made for each sampling point in the stream, and a net chemical flux for each subcatchment will be calculated as the difference between flux at the upper and lower sampling points of each stream segment. A similar computation will be done for discharge to obtain a net water flux for the sul atchment. The net chemical flux will then be divided by the net water flux to determine a "net concentration" for the subcatchment (Lawrence and Driscoll, 1990). These net concentration values will then be applied through the EMMA approach to determine the rels ive contribution of each subcatchment to downstream water quality. 
The percentage of each type of landscape in each subcatchment (such as hardwood hillslope, hemlock hillslope, wet-soil zone, and so forth) will then be calculated from spatial data available in the GIS data base and used to relate landscape type to spatial patterns of stream chemistry throughout the basin.

\section{Work Element 2. Modeling the Sources of Land- scape Effects on Stream-Water Quality}

Hypothesis.-The chemistry of stream water draining a particular type of landscape is the result of mixing of definable end-member solutions originating from specific positions along the hydrologic flow path of the watershed.

Objective.-To identify the watershed characteristics in each landscape area that affect the quality of water transported through that watershed, and to use end-member-mixing analysis to discern how key landscape types can affect stream chemistry.

Approach.-The EMMA model requires data on chemical concentrations of solutions in the hydrologic cycle, such as shallow soil water, ground water, and deposition. Solution samples from selected end-member sites in each of the catchments will be collected from four to six times. The soil plots for end-member sampling will be distributed evenly throughout the watershed, with particular focus on the Biscuit Brook, Winnisook, and Shelter Creek watersheds (fig. 1), where other data that support this study are being collected. Measurement techniques will depend on the chosen end member-for example, solutions from poorly drained soils will be sampled with piezometers or basters, whereas solutions from well-drained soils will be sampled with lysimeters. The most likely end members to be monitored during this study include the unsaturated-soil zone, the saturated-soil zone, the ground-water-discharge zone (seeps), stream water, precipitation, and ponded water. Soil water will be collected from soils beneath hardwood and hemlock forest stands. Sampling locations will be recorded in the GIS data base as a point coverage; unique identifying values will be directly related to the chemical data collected at these sites.

Soil water from well-drained soils will be collected by zero-tension lysimeters placed below each of the $\mathrm{Oa}$ and Bs soil horizons, and soil water in saturated soils will be sampled through shallow piezometers or skimmed from surface water with a baster. Seep-water quality will be monitored in all landscape aress used in the study.

The several wetlands, two clusters of small fish ponds, and one lake in the Neversink watersted could have a significant effect on stream-water qual ty downstream from their outlets. Initially, water quality and discharge at the inflow and outflow points of representative ponded waters, and in the Neversink River above and below the confluence with the ponded-water outlet, will be monitored. If these measurement:- indicate a significant effect on stream-water quality, a dditional monitoring will be done.

\section{Toplc D. Nonconservative Transport o* Nitrate and Aluminum in Stream Water}

Historically, many studies of stream and watershed hydrology and geochemistry have assumed that the stream channel acts as an inert pipeline that conservatively transports dissolved solutes downstrean (Johnson and others, 1969; Pinder and Jones. 1969). Since the 1970's, however, the effects of stream-channel and near-channel processes on the chemical evolution of stream water have gained increased attention (Robinson and others, 1979; Hill, 1981; Henriksen and others, 1988), although none of the recently developed small watershed models explicitly consider streamchannel processes (Cosby and others, 1985; DeWalle and others, 1988; Christophersen and others, 1990).

Nonconservative transport of many dissolved chemical constituents in rivers and streams in a wide variety of geographic locations has been documented (Hill, 1981; Christensen and others, 1990; Triska and others, 1990b). Within the Neversink River basin, nitrate is of particular concern because it play's a major role in acidification and could stimulate algal growth. The major processes that affect nitrate transport include: physical storage and release (Triska and others, 1990b), reduction (including denitrification and ammonification) in the near-stream zone (Cl ristensen and others, 1990), uptake by aquatic macrophytes (Casey, 1977), immobilization by the autotrophic and heterotrophic epilithic community (Kaushik and others, 1975), and oxidation (nitrification) ir stream sediments (Triska and others, 1990a). Because nitrification can be coupled with denitrification in stream sediments, the channel can serve as a nitrate source or sink, depending on which process is dominant. Several studies have found that denitrification is the dominant 
process in stream nitrate transport (Kaushik and others, 1975; Van Kessel, 1977; Hill, 1981; Christensen and others, 1990), but at least one study found a stream reach to be a net source of nitrate (Triska and others, 1990b).

In watersheds that are sensitive to acidic precipitation (have a limited capacity to neutralize strong-acid inputs), such as the Neversink, decreases in $\mathrm{pH}$ are accompanied by increases in aluminum concentration during high flows (Bums, 1989; McAvoy, 1989). These increases could result from the release of aluminum from the stream-channel substrate (Norton and Henriksen, 1983; Henriksen and others, 1984). In experiments in which acid was added directly to a stream, aluminum concentrations increased downstream, indicating the source of readily mobilized aluminum in the stream substrate (Hall and others, 1980; Henriksen and others, 1988). Most reports of aluminum precipitation in stream channels have been from areas affected by sulfide mineral oxidation (Theobald and others, 1963; Nordstrom and Ball, 1986), but at least one study has reported removal of dissolved aluminum by the substrate in a stream whose watershed does not have abundant sulfide minerals (Lawrence and Driscoll, 1990).

The Neversink Watershed Study will address the effects of stream-channel processes on the chemical evolution of aluminum and nitrate in stream water. Stream reaches that collectively represent the range of water chemistry and substrate conditions found within the watershed will be identified and mapped as polygon coverages in the GIS data base. After detailed study of selected stream reaches, results will be extrapolated to the entire Neversink River watershed on the basis of stream-channel information stored in the GIS data base.

\section{Work Element 1. Nitrate}

Hypothesis.-Stream-channel processes have a significant effect on the downstream transport of nitrate in the Neversink River.

Objectives.-(1) To determine whether representative stream reaches are sources or sinks of nitrate and estimate the annual variability of stream-reach uptake or release; (2) To quantify the relative roles of physical and biotic storage and release in the downstream transport of nitrate in representative stream reaches; (3) To quantify the relative importance of denitrification and immobilization by substrate materials as within- channel sinks of nitrate in representative stream reaches. (This objective will be pursued only if the selected stream reaches show significant nitrate losses); (4) To extrapolate results from the above objectives to the entire Neversink watersh?d.

Approach.-A reconnaissance of the I 'aversink River will be done to select two or three re sresentative stream reaches (200 to $800 \mathrm{~m}$ long) for study. Streamchannel characteristics will be incorporate 1 into a GIS coverage of stream data. Maps and aerial photographs will be examined to locate representative stream reaches. Two of the reaches will represent contrasting substrates; the first will be quiescent with abundant sunlight and an organic-rich substrate, and the second will be energetic, with abundant pools and riffles, beneath a closed forest canopy. If necessery, a third reach will be selected for detailed study to ropresent the diversity of stream-channel types.

Two to four shallow wells will be driven into the stream channel or just adjacent to the stream in each reach during the first year, after selection of stream reaches. These wells will be made of stainless steel and have a $31-\mathrm{cm}-$ long screen and a drive point at the end.

One- to 2-day mass balances of nitrate, ammonium, and chloride will be calculated for each stream reach during four seasonal conditions - early spring with high base flow; late May, just after canopy development; mid- to late summer, during maximum nitrogen uptake; and early October, during leaf fall. These conditions were selected to represent a rarge of light, temperature, flow, and organic-matter inpit that are thought to affect nitrate transport.

To estimate the mass balances, flow will be measured with a current meter at the upstream and downstream ends of each reach near the beginning and end of each 24-hour period. Measurements will be made when rain is not expected. If significant rainfall occurs during the measurement period, the experiment will be discontinued until flow conditions stabilize. A reference point will be established near the upstream and downstream ends of each reach, and the water-surface elevation (stage) will be measured frequertly during the 24-hour period to record the variations in flow. Samples will be collected at the upstream and downstream ends of each reach every 2 hours. A dditionally, at least two samples will be collected daily during the 24-hour period from each well and tributary along the reach. 
Mass balances of nitrate, ammonium, and chloride will be calculated for each reach to determine whether the channel is a net source or sink for nitrate and ammonium. Chloride will be assumed to be transported conservatively and will be used to check the uncertainty of each mass-balance calculation. Data from well and tributary samples will be used to calculate additions to or losses from the stream reach if flow measurements indicate that the reach is gaining or losing water. The mass balances will reveal the extent of nitrate gain or loss through a given stream reach and the degree to which downstream changes in concentration vary with substrate type and season and with light, temperature, flow, and organic-matter input. Concentration changes between day and night will indicate the extent of autotrophic uptake relative to denitrification if the stream is a net nitrate sink.

Mass balances over short periods of time will reveal whether a given stream reach is a source or sink for nitrate, but they will not indicate how much of the change in downstream load is the result of abiotic processes rather than biotic processes. To address this question, a series of tracer experiments will be performed during the second year. A tracer containing a nitrate-bearing salt and a conservatively transported salt (chloride or bromide) will be pumped into each stream reach at a location far enough upstream from the top of the reach to allow complete mixing. The tracer will be pumped into the reach for several days at a known rate and at a concentration high enough to raise stream concentrations of each constituent to 20 to 50 percent above background concentrations. Samples will be collected frequently at the beginning and end of the experiment, and less frequently once steady-state concentrations are reached. The tracer experiment will be done on each reach during at least two contrasting seasonal conditions. Precipitation will be sampled at a collector along each stream reach to account for direct deposition during the experiment. Additionally, the wells and tributaries will be sampled frequently during the tracer experiments.

The mass flux of the conservative tracer will be compared with the mass flux of nitrate to determine how much of the storage or release of nitrate is physi$\mathrm{cal}$; the difference between total storage or release and physical storage or release will be attributed to biological processes. If rainfall is significant during any of the tracer experiments, the data will be used to determine how the ratio of physical to biotic uptake or release varies with flow.
Results of the mass-balance calculations and tracer experiments will identify which stream reaches are sources or sinks of nitrate. Physical and biolc sical characterization of the stream reaches in which these processes have been identified, and subsequent analysis through the GIS data base, will enable extre solation of the results to other parts of the Neversink watershed.

The nitrogen cycle in streams is complex and has several potential sources and sinks, many of which are difficult to quantify. The approach discussed above assumes that processes such as uptake by aquatic macrophytes are negligible in a mass-balance calculation for nitrate, if, for example, the stream channel contains large quantities of moss, but the approach may have to be revised. Detailed observations of each stre $m$ reach, and examination of the effects of varying seas nal conditions on nitrate transport, may suggest changes in the approach. A few select analyses of stream water, ground water, and periphyton for ${ }^{15} \mathrm{~N} /{ }^{14} \mathrm{~N}$ ratios could provide additional information on nitrogen tr'nsport, and if these analyses provide information on streamchannel nitrate cycling, further sampling and analysis will be done.

\section{Work Element 2. Aluminum}

Hypothesis.-Aluminum is removed from solution in the Neversink River in reaches where strerm-water $\mathrm{pH}$ increases significantly over a short distan?e.

Objectives.-(1) To determine whether aluminum is removed from solution in the Neversink River channel in selected stream reaches where $\mathrm{pH}$ at the upstream end is less than 5.5 during the samf $F^{1} e$-collection period and increases more than $0.5 \mathrm{pH}$ units in less than $800 \mathrm{~m}$, and (2) to determine the temporal and spatial variability of aluminum removal or its release from the substrates in selected reaches of the $\mathrm{T}$ 'eversink River during spring and fall.

Approach.--Initially, reconnaissance sampling of the Neversink River watershed will be done to select two stream reaches in which base-flow $\mathrm{pH}$ at the upstream end is usually less than 5.5 and inc "eases by at least $0.5 \mathrm{pH}$ units within a distance of $800 \mathrm{~m}$. At least four sampling locations will be selectec within and just downstream from each reach. Samples will be collected from these sites as quickly as possible on a given day in the early spring and again in the fall. Discharge will be measured at the upstream and downstream ends of each reach as the samples are collected. 
Samples will be analyzed for all major chemical constituents, three fractions of dissolved aluminum (total monomeric, organic monomeric, and total), and fluoride. An attempt will be made to select sampling locations that coincide with stream-gaging locations.

Discharge measurements will be used to calculate an instantaneous aluminum mass balance for each reach.

Data from all sampling sites will be entered into the GIS data base as a point coverage, the identifying values of which will be directly related to the waterquality and streamflow data collected along the specified stream reaches. The uptake and release of aluminum in relation to stream-water quality will be analyzed through the digital data base.

An equilibrium thermodynamic model

(ALCHEMI or WATEQ) will be used to calculate saturation indices for the common aluminum-bearing minerals that are likely to control aluminum activity in solution. The saturation indices will provide a reference state against which changes in aluminum concentrations in relation to $\mathrm{pH}$ can be compared. If the saturation indices and mass-balance fluxes indicate that aluminum is precipitating from solution as $\mathrm{pH}$ increases, an additional experiment will be performed in which stream sediment from another location will be placed in Nytex ${ }^{1}$ bags and submerged for several months at selected locations above and within the stream reach. At the end of the experiment, the bags will be removed and the sediment dried, and a series of extractions will be performed to identify the forms of exchangeable and solid-phase aluminum (McKeague and others, 1971). A clean sediment sample that has not been submerged will be compared with the other samples; the presence of significant amounts of aluminum in the sediment in a stream zone in which massbalance and equilibrium thermodynamic calculations indicate aluminum is precipitating will help to confirm the results.

\section{Topic E. Nitrogen Cycling}

The cycling of nitrogen within forest ecosystems is extremely complex and involves many plant and microbially mediated biochemical reactions, as well as chemically controlled transformations and physical

1. Use of trade, product, or firm names in this publication is for descriptive purposes only and does not imply endorsement by the U.S. Govemment. transport mechanisms. One method of evaluating the net result of these processes is to compare nitrogen inputs in the ecosystem with the outputs. Because changes in the nitrogen cycle could altrr stream-water quality, a nitrogen-monitoring program will be established in Winnisook watershed, the source watershed of the West Branch Neversink River (fig. 1). Annual nitrogen input-output budgets will be estimated for subbasins within the Winnisook Water: hed and for the entire watershed. Because the Winnisnok watershed faces northwestward and drains the highest elevations of the West Branch Neversink watershed, atmospheric deposition is likely to be greater here than elsewhere in the Neversink basin. Therefore, if forert ecosystems in the Neversink basin are approaching nitrogen saturation, the first effects on water quality w'ould be seen in the Winnisook watershed.

Development of chemical input-output budgets requires definition of ecosystem bouncaries. In this study, watershed divides will serve as lateral boundaries, and the top of the forest canopy and bottom of the solum will serve as upper and lower bc'undaries.

Because neither bedrock nor till in the l'eversink basin contain significant quantities of nitrogen, and because nitrogen-fixing plant species are rare, ritrogen can be introduced into the system only through atmospheric deposition.

To measure the amount of material deposited from the atmosphere is extremely complicated. Atmospheric deposition occurs by three prin-ipal mechanisms: (1) wet deposition, including rain and snow; (2) dry deposition or the direct deposition of particles (such as salts, acid aerosols) and gases (such as sulfur dioxide and nitrogen oxides) onto vegetation surfaces, and (3) cloud-water deposition of nonfrecipitating cloud droplets onto vegetation immersed in cloud or fog. All three contribute significantly--wet deposition tends to dominate in areas far from the ritrate-emission sources, whereas dry deposition tends to dominate in areas close to those sources; cloud-water deposition can dominate in areas frequently exposed to fog or low clouds, such as mountain tops and seacoasts. Of the three, only wet deposition is easily and routinely measured; dry deposition must be estimated from air concentrations and deposition velocities, which are determined from hydrodynamic models that are sensitive to topographic and canopy variations. Cloud-water deposition is estimated from collectors that simulate the forest canopy. Throughout most of the eastern U.S, 
the amount of nitrogen contributed in dry deposition is equal to or greater than the amount contributed in wet deposition, even in rural areas; therefore, measurements fail to account for at least half of the total deposition (Lindberg, 1992; Lovett, 1992).

The difficulty in estimating total deposition is increased in mountainous terrain by the highly variable meteorological and forest-canopy characteristics. For example, high elevations in the Catskill Mountains can result in (1) larger amounts of precipitation than at lower elevation, (2) greater wind speeds, which enhance dry and cloud-water deposition, (3) coniferous rather than deciduous forest, which increases the deposition of some particles and gases but can decrease the deposition of other gases, and (4) an increased amount of time in which the forest is within clouds (Lovett and Kinsman, 1990). Together these factors result in atmospheric-deposition rates at high elevations that can be more than four times greater than those at nearby low elevations (Lovett and Kinsman, 1990).

Nitrogen is an essential nutrient for plant and microbial growth, and several processes can effectively immobilize nitrogen within the forest canopy and rooting zone. For this reason, nitrogen inputs tend to greatly exceed outputs in undisturbed forest ecosystems. Mechanisms for ecosystem loss of nitrogen include (1) release of gaseous compounds to the atmosphere (primarily as $\mathrm{N}_{2} \mathrm{O}$ or $\mathrm{N}_{2}$ ), (2) transport in both dissolved and particulate forms by surface water, and (3) infiltration into the soil. In undisturbed, forested watersheds with well-drained soils, most nitrogen is lost as dissolved $\mathrm{NO}_{3}^{-}$or $\mathrm{NH}_{4}^{+}$through surface-water transport (Likens and others, 1977); therefore, measuring nitrogen losses in streamflow is simpler than estimating nitrogen inputs by atmospheric deposition. Outputs in surface water can be quantified through continuous flow measurements and periodic chemical analysis of stream water leaving the watershed. The frequency of sampling depends on the magnitude of temporal variation in stream-water nitrate concentrations.

\section{Work Element 1. Quantifying Nitrogen Budgets}

Hypothesis.-Low-order watersheds in the Neversink basin are approaching nitrogen saturation.

Objective.-To (1) quantify annual nitrogen inputs and outputs in subbasins, (2) evaluate elevational patterns of nitrogen cycling, and (3) obtain baseline conditions necessary to identify future changes.

Approach.-Because total atmospheric deposition of nitrogen is difficult to measure, a combination of atmospheric and ecosystem measurements will be used to evaluate the elevational patterns of deposition. Precipitation will be collected with an automatic wetfallonly collector, air samples will be collected with a filter-pack system, and throughfall depositior (the deposition of chemicals in water that drips through the forest) will be collected with a network of funnel collectors under selected forest stands.

A reference site for measurement of wet and dry deposition will be established lower in the basin, at about $730 \mathrm{~m}$ elevation. The site will be in a clearing with AC electric power and will contain an a'tomatic precipitation collector (for chemical analysis) and an air-quality-measurement system. The syster consists of a flow-controlled pump that draws air at 3 to $5 \mathrm{~L} / \mathrm{min}$ through at three-stage filter pack that traps atmospheric particles and the gases $\mathrm{HNO}_{3}$ and $\mathrm{SO}_{2}$ on specially treated filters. The filter pack will be installed on a tiltable 5-m mast, and the pump and flow contmller will be placed in a weatherproof enclosure. In acdition, wind speed and direction, temperature, relative humidity, duration of foliar wetness, and solar radiation will be measured with a meteorological measurement system and data logger. The meteorological data will allow (1) estimation of dry deposition from the measured atmospheric concentrations through a dry-deposition model in common use throughout the U.S. (Hicks and others, 1986), and (2) determination of how concentrations of airbome pollutants are related to the wind direction and, presumably, the general source areas of the pollutants.

Chemical deposition is more difficult to measure than atmospheric chemical concentrations, and methods of measuring the deposition of dry partic's's, gases, and cloud droplets are not well established and are the subject of current research (Hicks, 1986; Lo'ett and others, 1992). One method of measuring atmospheric deposition that appears to be gaining considerable support is collection of throughfall (Lindberg and Garten, 1988), but because forest canopies take up atmospheric $\mathrm{N}$, measurement of throughfall probably underestimates total nitrogen deposition. This does not apply to sulfur, however; recent research ind : ates that forest canopies neither take up nor release sionificant quantities of sulfur in rain that flows over them (Lindberg and Garten, 1988). If the rain washes off sulfur 
deposited as gases, particles, and cloud droplets, as well as that deposited in rain, then the total atmospheric deposition of sulfur (wet + dry + cloud) can be directly measured by the collection of throughfall. A strong correlation has been shown between the amount of $\mathrm{SO}_{4}{ }^{2}$ in throughfall and the total sulfur deposition as estimated by independent methods (Lindberg, 1992, fig. 2). Collection of throughfall to measure atmospheric deposition in remote, mountainous areas is advantageous because the measurement does not rely on models of deposition velocity that are sensitive to variations in topography, and collectors do not require electricity.

Measurements of throughfall-deposition of sulfur will be used to estimate elevational patterns of total nitrogen deposition that cannot be measured directly without installation of air-quality-monitoring equipment throughout the watershed. Previous research suggests that elevational pattems of sulfur deposition are similar to those of nitrogen (Lovett and Kinsman, 1990). In this approach, a relation will also be developed between nitrogen deposition in throughfall and in dryfall at the base of the watershed. This information will then be integrated with the throughfall-deposition measurements at other locations to evaluate spatial patterns of total nitrogen deposition and to estimate annual nitrogen deposition at a subbasin scale and wholewatershed scale.

Throughfall will be collected in 80 funnel collectors placed in clusters of five along a line from the base of the watershed to the top. The throughfall solutions will be collected weekly during spring, summer, and fall, and retumed to the laboratory for analysis for $\mathrm{NO}_{3}, \mathrm{NH}_{4}^{+}$, and $\mathrm{SO}_{4}{ }^{2-}$. The five samples from each cluster will be composited into one sample before analysis to minimize analytical costs. During winter (November 1 through April 1), samples will be collected biweekly in frame-supported polyethylene bags. Total throughfall flux of each constituent will be calculated as the product of concentration and water volume for each site and sampling period. Incident precipitation will also be measured year-round by a standard wet-only collector in the open area at the base of the watershed and in a small clearing near the top, and analyzed for nitrogen and sulfur.

Losses of nitrogen from Winnisook Watershed will be calculated from flow measurements and biweekly sampling described in Topic A, Work Element 1.
Samples will also be collected during storms to monitor changes in concentrations that often crcur during changes in flow. Biweekly water samples will be analyzed for dissolved $\mathrm{NO}_{3}^{-}$and $\mathrm{NH}_{4}^{+*}$; storm samples will be analyzed for these constituents and total suspended N. All sampling-location data and water-quality data will be maintained in the GIS data base and will be used to quantify nitrogen inputs and outputs and to analyze spatial patterns of nitrogen deposition in the watershed.

Nitrogen inputs and outputs will be monitored for 4 consecutive years; efforts will be made to resume measurements 5 to 10 years later. Quantifying nitrogen inputs and outputs will provide detailed taseline information that will be useful in evaluating any future changes that might result from changes ir atmospheric deposition or climate. The nitrogen-budget data will also be compared with data from other sites in the Northeast to investigate the status of Winnisook watershed in relation to similar sites that receive different amounts of atmospheric deposition.

\section{Toplc F. Water Quallty and Its Effe?ts on Aquatic Blologlcal Communitles}

Catskill rivers have historically supported self-sustaining brook trout (Salvelinus fontinalis Mitchell) populations. Since the mid-1960's, however, acidic deposition has degraded water quality and adversely affected aquatic communities in several Catskill rivers, including the Neversink (Colquhoun and others, 1984; Murdoch and others, 1991; Stoddard and Murdoch, 1991). Much of the East Branch of the Neversink River, as well as many low-order reaches in the West Branch, lack viable populations of indigenous fish species such as brook trout (U.S. Geological Survey, unpublished data, 1992). Although fish can be found in most reaches of the Neversink River, juvenile age classes are commonly missing, community diversity typically is low, fish condition is poor, and natural reproduction appears to occur only in well-buffered tributaries. In the East Branch of the Neversink River, prey species such as the slimy sculpin (Ccttus cognatus Richardson) now are found only in a few low-order tributaries. Aquatic macroinvertebrate communities have also been affected in most reaches of the Neversink River (U.S. Geological Survey, unpıblished data, 1992). 


\section{Effects of Acidification on Fish and Invertebrate Populations}

Laboratory toxicity experiments and field investigations have demonstrated that low $\mathrm{pH}$ and high aluminum concentrations, alone and in combination, can be toxic to fish (Schofield and Trojnar, 1980; Baker and Schofield, 1982; Parkhurst, 1987; Mount and others, 1988; Baker and Christensen, 1991). The inorganic form of aluminum is biologically available and therefore is usually the fraction most highly correlated with inhibition of brook trout growth and increased mortality during laboratory toxicity tests (Driscoll and others, 1980; Baker and Schofield, 1982; Mount and others, 1988). Inorganic aluminum concentrations also appear to be a primary factor limiting fish survival and populations in acidified lakes and streams (Parkhurst, 1987; Schofield and Driscoll, 1987; Johnson and others, 1987; Baker and others, 1990).

Surface-water acidification also affects aquatic macroinvertebrates and their benthic communities. Unlike fish species, however, invertebrate mortality tends to be most related to ambient $\mathrm{pH}$ levels (Raddum, 1980; Baker and others, 1990). The response to acidification differs greatly among invertebrate species because of wide differences in their physiology, lifehistory strategies, and ecology (Havas, 1981; Pratt and Hall, 1981; Hall and others, 1987; Raddum and Fjellheim, 1984). This range in species tolerances tends to mediate community responses associated with acidification, although changes in structure and function (species replacements) are often noted (Baker and others, 1990). Because macroinvertebrate species have short generation times, and many species are sensitive to acidic conditions, they are excellent bioindicators of acidification trends (Raddum and Fjellheim, 1984; Okland and Okland, 1986).

\section{Mechanisms of Fish Stress and Mortality}

Inorganic aluminum and $\mathrm{H}^{+}$invoke stress and mortality in fish through several interrelated physiological mechanisms. Concentrations of inorganic aluminum above $5 \mu \mathrm{mol} / \mathrm{L}$ and(or) $\mathrm{pH}$ below 6.0 can alter bloodion balances, which can lead to osmoregulatory damage to essential tissues and organs (Daye and Garside, 1976; Packer and Dunson, 1972; Gagen and Sharpe, 1987). Both low pH (below 4.5) and elevated aluminum concentrations (above $11 \mu \mathrm{mol} / \mathrm{L}$ ) can cause suffocation from excess production of mucus, erosion or expansion of membrate, and accumulation of aluminum precipitates at the gill surfoce (Packer 1979; Schofield and Trojnar 1980; Leivestad 1981; Cleveland and others, 1986).

Sensitivity of organisms and degree of toxicity of surface waters often changes as a result of complex hydrogeochemical interactions within watersheds. For example, calcium seems to enhance bronk trout tolerance to toxic levels of inorganic aluminum and $\mathrm{H}^{+}$by increasing efficiency of $\mathrm{Na}$ regulation ( $\mathrm{N}$ /ount and others, 1988). Increased concentrations of dissolved organic carbon can also decrease the toxicity of aluminum and $\mathrm{H}^{+}$in streams by increasing the organic fraction of monomeric aluminum and decreasing the biologically available inorganic fraction- (Baker and Schofield 1982; Parkhurst, 1987).

In streams where acidic tributaries with elevated dissolved aluminum concentrations mix with waters that have a positive acid-neutralizing caracity, oversaturation with respect to the controlling mineral phase may occur; oversaturation with respect to dissolved aluminum can result in significant fish mortality at $\mathrm{pH}$ and aluminum levels that would be nonlethal under equilibrium conditions (Schofield and Trojnar, 1979; Cleveland and others, 1986; Parkhurst, 1987). During oversaturation conditions, aluminum can readily sorb to gill tissue and result in suffocation ant, under extreme conditions, precipitating aluminum has been shown to disrupt benthic macroinverteb-ate communities (McKnight and Feder, 1984). Althc' 'igh evidence from laboratory experiments indicates th at aluminum solubility affects fish mortality, it has nct been investigated under natural conditions. Preliminary sampling suggests that oversaturation of aluminum with respect to a controlling mineral phase occurs in several locations in the Neversink basin.

\section{Use of Biological Indices in Characterizing Water Quality}

Stream-water quality has traditionally been defined in terms of measured chemical concentrations and laboratory tests in which levels of reconstituted toxins are kept constant throughout the experiment. This approach often poorly represents conditions in natural systems, however, because (1) stream-water chemistry can change significantly over a few hours (Murdoch and others, 1991), whereas water samples are seldom collected more often than weekly, and (2) 
water chemistry can vary over distances of $10 \mathrm{~m}$ or less (U.S. Geological Survey, unpublished data, 1992), whereas sampling is seldom done over sufficiently short distances to detect these local changes. These spatial and temporal variations in water quality can affect survival of fish and macroinvertebrate populations. Because mortality is a function of the duration and frequency of exposures, as well as the toxin concentration, local variations can provide refuges wherein individuals and populations can avoid toxic conditions.

To overcome the difficulty in accurately characterizing water quality from chemical analyses of water samples and relating chemistry to results from laboratory toxicity tests, biological indices have been developed that relate factors such as population density and biomass of key species or species assemblages to those that would be expected in natural (unpolluted) conditions. One commonly used index is the Index of Biological Integrity (IBI) developed by Karr and others (1986). In this approach, a score is developed for a particular site, whereby a number from 1 to 5 is assigned to each of 12 operationally defined measurements that reflect characteristics of the fish community. The 12 measurements are divided into three general categories: (1) fish-community richness and composition, (2) trophic composition of community, and (3) fish abundance and condition. Water quality is evaluated through a comparison of the total score with scores that were previously developed for similar habitats considered to be pristine. The IBI of Karr and others (1986) was specifically developed for large rivers but could be useful for evaluating effects of episodic acidification in headwater streams.

\section{Work Element 1. Aquatic Toxicity}

Hypothesis.-Survival of biota in streams in which aluminum toxicity varies on a temporal and spatial basis can be predicted by Al-solubility relations.

Objective.-To determine the effect of Al-solubility relations on fish and macroinvertebrate condition and mortality.

Approach.-Toxicity tests on brook trout (Salvelinus fontinalis), midge larvae (Chiroromus tentans), and one endemic species of mayfly in the genus Ephemeroptera will be conducted twice each year at 7 to 11 sites on the Neversink River. Water chemistry will be monitored frequently at each site during test periods.
The effect of spatial differences in stream chemistry on fish and macroinvertebrate mortality at each site will be assessed during spring and fall periods. Relations between organism mortality and cc ncentrations of biologically important constituents, principally $\mathrm{Al}$, will be developed. Because aluminum concentrations and speciation and streamflow during base-flow conditions are relatively stable, the effects of differing watershed characteristics on aluminum solubility and toxicity can be defined.

Effects of fluctuations in toxicant concertrations on organism survival will be assessed through a comparison of results of toxicity tests at sites that experience severe acidification episodes. The concentration of many chemical constituents can change sharply in less than 1 hour and generally is related to stroam discharge. Because mortality resulting from changing water quality is related to several factors, it will be correlated with various statistics that quantif? either magnitude, duration, or frequency of fluctuations in the concentration of selected toxins. Toxicity tests will be done in conjunction with water-sampling op?rations associated with the investigation of in-stream aluminum chemistry (topic E). Additional water $\mathrm{s}^{\wedge} \mathrm{mples}$ and flow measurements will be taken, as nee ted, to ensure that all water-chemistry fluctuations d uring toxicity tests are measured.

The water-quality sampling sites and bioassay locations will be entered into the GIS data bas? as point coverages, and the effect of aluminum solubility and other water-quality factors on fish and macrc invertebrate mortality will be analyzed through the digital data base. The correlations developed by these analyses will be used to predict mortality rates of fish and macroinvertebrate species in the remainder of the Neversink watershed.

Because brook trout are the most common game fish in the upper reaches of the Neversink River and have intermediate sensitivity to acidification, they will be used in all fish-toxicity tests. Young-of-the-year fingerling trout will be used for each test $(\mathrm{ag} ?=<1$ year). All brook trout will be obtained from East Branch tributaries to ensure a common-pool source of fish and minimize effects that differing heredity and (or) exposure histories could have on tolerance and mortality. In each test, 20 to 30 brook trout will be placed in each of four or five plastic, screen-sided jugs installed in holding cages in slow-moving water protected by channel structures. At each site, the fish 
will be exposed to water for at least 30 days and will be checked daily during exposure periods.

One or more insect species will be used to assess the effects of acidification on the benthic macroinvertebrate community. Midge larvae (Chironomus tentans (Fabricius)) tests will use late instar larvae from cultures maintained by the New York State Department of Environmental Conservation (NYSDEC) at the USGS laboratory in Albany. At least 20 larvae will be added to three screen-sided polyethylene containers and placed adjacent to the brook trout cages at each site. Because the chironomid larvae emerge from the water (as adults) after about 30 days (at $25^{\circ} \mathrm{C}$ ), the test duration might shorter than the trout tests. The life spans of most mayfly and stonefly species are much longer than that of chironomids, and some species are highly sensitive to acidification. Therefore, if sufficient numbers can be collected with minimal stress and damage to individuals, toxicity tests will be conducted on at least one endemic macroinvertebrate species.

Response of Chironomus tentans and a readily available indigenous species will be compared with bioassay information reported in the literature to assess their representativeness as water-quality indicators.

\section{Work Element 2. Integrity of Biological Communities}

Hypothesis.-Biological indices reflect the spatial and temporal variability of water chemistry in the Neversink River.

Objective.-To measure and evaluate standard and integrated biological-community indices that characterize spatial and temporal variations in water quality in the Neversink River.

Approach.-Fish and macroinvertebrate communities will be sampled in conjunction with water sampling at representative mainstream and tributary sites throughout the Neversink River basin to characterize present conditions. Sampling locations and waterquality measurements will be entered into the GIS data base. Standard measures and indices will be compared with indices that integrate selected physical, chemical, and biological measures (hereafter referred to as integrated indices) to identify those that correlate best with water quality and most effectively predict biological consequences of chronic and episodic acidification. Spatial information on fish and macroinvertebratecommunity characteristics (measures and indices) will be incorporated into the spatial watershed model.
Standard biological measures and indices to be evaluated include: community diversity and richness, indicator species, species assemblages, fisl condition, fish and macroinvertebrate-population dencities and biomass, fish-age distribution, and fish-gre wth rates. Indices that integrate several biological and chemical measurements that reflect acidification will also be developed and refined if possible. These vill include the IBI (Karr and others., 1986), the Ephem eroptera-toPlecoptera Ratio, and the biological multim tric profile (R. Bode, New York State Department of Environmental Conservation, unpublished data), and the Biological Monitoring Working Party system (BMWP' (Armitage and others, 1983). Variability of fish communities could be a result of stream or site differences in food supply, physical habitat quality, competitic n, availability and use of refuges, predation and fishin? pressures, and fecundity. Several of these factors will be investigated directly through macroinvertebrate inventories, special fishery surveys (that assess use of mfuges), and physical-habitat characterizations. Physical characteristics of sampling sites will be examined to determine whether differences in fish and macroinve tebrate communities might also be related to differences in physical habitats. For example, the riverire Habitat Suitability Index (HSI) (Raleigh, 1982) represents a measure of suitability for several physical stream characteristics known to affect the survival ant growth of embryo, fry, juvenile, and adult brook trout.

Fish sampling will be done at most siter at which a streamflow gage has been installed and water samples are routinely collected for chemical analyses (fig. 2 ). Water-quality and fish characteristics will be entered into the GIS data base as point coverage. Several ungaged sites will be selected for additional sampling. Fish communities will be sampled annually at low flows in late July and early August; some mid-spring and late-fall fish surveys will also be conducted at several sites to assess seasonal fish movement and use of refuges. Fish populations will be sampled by electroshocking in seine-blocked 50 - to 100 -m rearhes. Three passes will be used to collect as many individuals as possible. After each pass, the length and r'eight of individual fish will be measured and recorted, with species counts, on field forms. Growth ant survival rates for each fish species will be determired from frequency distributions of body length. Population levels and confidence limits will be estimatec by the Moran-Zippin proportional model (Zippin. 1958). 
Macroinvertebrate populations at selected sites will be sampled by a standard Surber sampler. One or two inventories will be done at gaged sites in conjunction with midsummer fishery inventories, and results will be entered into the GIS data base. At each sampling location, three replicate samples will be collected by stirring up stream substrate within the Surber grid to force debris and macroinvertebrates into a downstream net. Specimens and organic debris collected in this manner will be separated from coarse rock, gravel, and sand by rinsing in a sieve-bottomed bucket $(500 \mathrm{~mm})$ and then preserved in 80-percent ethanol. The remaining material will be inspected for large macroinvertebrates. Specimens will be taken to a processing laboratory for sorting, identification as to genus (and species when possible), and enumeration.

At gaged sites, stream-chemistry and flow data will be provided from routinely collected water samples and stage-to-discharge relations. At ungaged sites of special interest, water samples will be collected, and discharge will be measured during fish surveys. At these sites, additional water samples will also be collected periodically to develop concentration-to-discharge relations that can be used to predict chemical concentrations from flow. Statistics of biologically important chemical constituents will be summarized on an annual basis for comparison with community-integrity indices. These data will be maintained in the GIS data base of sampling sites.

Basic water-quality statistics will be supplemented with integrated indices such as the ASI, which calculates brook trout mortality levels from aluminum, acidity, and calcium concentrations (Ingersoll and others, 1988; Baker and others, 1990). The ASI will be compared with observed mortality (results of onsite toxicity tests), inorganic $\mathrm{Al}$, and biotic community indices to evaluate its association with and its potential ability to predict biological-community integrity. All biological measures and indices will be correlated with the concentration of selected chemical constituents to evaluate their ability to quantify the quality of stream waters. All measures of biologic and water quality will be entered into the GIS data base and used to develop a conceptual model of biological diversity in the Neversink basin. Relations between water quality and various indices will enable development of spatial models that describe aquatic species and community distributions in the Neversink River. These models can ultimately be used to develop strategies to monitor changes in water quality and to predict the cl anges in ecosystems that could result from differing rates of atmospheric deposition of acids within the Naversink watershed.

\section{GEOGRAPHIC INFORMATION SYSTEM (GIS) SUPPORT ACTIVITIES}

Geographic Information Systems comprise computer hardware and software that are designet to collect, manipulate, manage, analyze, and display spatially referenced data. ARC/INFO, devel pped by the Environmental Systems Research Institut : (ESRI), organizes geographical data through a relatic nal and topological model. This GIS used for the Neversink watershed Study relates the location and topology of map features to attribute, or descriptive, data at a scale of 1:24,000. The following coverages will be developed:

Watershed Boundaries.-Drainage-basin and subbasin boundaries of the Neversink watershed have been delineated on USGS topographic quadrangle maps. These boundaries will then be digitized, edge-matched, and edge-joined.

Hydrography.-Surface water and related features-streams, ponds, reservoirs, springs, and aqueducts-in the Neversink watershed and vicinity will be digitized from stable-base USGS topographic quadrangle maps that are reproduced by the New York State Department of Transportation. Arcs and polygons in each coverage will be coded to correspond to USGS Digital Line Graph (DLG) attribute coding standards. The coverages will be edge-matched, edge-joined, and appended into a single coverage.

Land Use/Land Cover.-Stable-base land-use/landcover maps from the Land Use and Natural F esources Inventory are available from the Comell Laboratory for Environmental Applications and Remote Sencing. The maps will be scanned on a Tektronix autovectorizing scanner at the USGS GIS Research Laboratory in Reston, Va. The vectorized data will then be converted to ARC/INFO polygon coverages. Each polygon will be coded according to the Land Use and Natrural Resources Inventory classification. The coverages will be edge-matched, edge-joined, and appended into a single coverage.

Hypsography.-Topographic contours from USGS topographic quadrangle maps will be isolated from 
other map features so that contours can be scanned. The New York State Department of Transportation will use these separations to prepare negatives of maps with contours and their elevation values, in feet. The negatives will then be scanned with a Tektronix autovectorizing scanner at the USGS GIS Research Laboratory in Reston, Va. The vector data will be converted to ARC/INFO line coverages, which will be edited and coded to correspond with the source materials.

Soils.-Soil surveys produced by the Soil Conservation Service (SCS) will be recompiled onto 7.5-minute topographic quadrangles. These maps will then be digitized at the Soil Information Systems Laboratory at Cornell University, and the accuracy will be maintained according to SCS national digitizing standards. These data will be converted to ARC/INFO polygon coverages, and the Soils Attribute Data Base will reside in the.PAT (polygon attribute table) of each coverage.

Wetlands.-Wetlands data are available from two sources: (1) regulatory wetlands maps that have been digitized by the New York State Department of Environmental Conservation Habitat Inventory Unit, as required by the Freshwater Wetlands Act (Article 24 of the Environmental Conservation Law), and (2) wetlands maps that were generated by the Cornell University Laboratory for Environmental Applications and Remote Sensing from the interpretation of aerial photographs as part of the Land Use and Natural Resources Inventory. These data will be evaluated to determine which will be most useful for the Neversink data base. Data from the Cornell Laboratory will be scanned and coded with polygon attributes that correspond to the source materials.

Forested Land.-Forested-land data from the Land Use and Natural Resources Inventory will be acquired from the Cornell University Laboratory for Environmental Applications and Remote Sensing. The forested lands are classified as brushland, natural forest, and plantations. After these data have been scanned and converted to ARC/INFO polygon coverages, the forests within each of these categories will be further classified as hardwood or coniferous through use of aerial photographs.

Sampling Sites.-All sampling sites will be represented in point coverages containing unique identifying values that are consistent with all relational data bases. The variables measured at each of the sites will be directly related to their geographic location in the
Neversink watershed. This data base will enable spatial analysis and display of physical, ch?mical, and biological data.

\section{DELIVERABLES}

Products resulting from this project will be (1) a conceptual spatial model of factors that control stream chemistry, (2) a basinwide characterizatior of the effects of acidic deposition on stream chemistry, and (3) nitrogen input-output budgets for Winrisook watershed.

1. Conceptual Spatial Model.-The major product resulting from the research and data-collection programs within this project will be a conceptual model that spatially relates watershed factors that control stream chemistry within the Neversink basin. This will be the first spatial model of stream chemistry to describe natural processes and effects of acidic deposition at scales greater than those of small watersheds. Historically, little or no information on water quality was collected in intermediate-size watersh:ds such as the Neversink before degradation by acid $d:$ position or other forms of pollution. Goals of remediation efforts, therefore, are often set without complete information on the cost and benefits associated with various levels of water-quality improvement. Because the Neversink basin is relatively undeveloped (with respect to other Catskill watersheds), the Neversink spatial model will be useful in developing a Catskill watershed-management plan. By providing a control with which other watersheds can be compared, the Neversink model can be used as a foundation for a management model that incorporates a variety of development scenarios. Many of the new approaches that will be needed to build the Neversink spatial model will also be used to evaluate the effects of disturbance.

2. Characterizing Effects of Acidic Deposition.In addition to providing information on natural watershed processes, this project will provide a basinwide characterization of the effects of acidic deposition. Whereas previous research has shown that acidic deposition is affecting stream-water quality within parts of the Neversink basin, this project will document the extent of the spatial and temporal effects of acidic deposition, including effects on the distribution of fish and aquatic invertebrate populations.

3. Nitrogen Budgets. - Through this Foject, a monitoring program will be established to evaluate the 
current status of nitrogen cycling within the headwaters of the basin. If forested watersheds in the Catskills are approaching nitrogen saturation, $\mathrm{NO}_{3} \cdot$ concentrations in stream water could increase from current levels without an increase in atmospheric deposition $\mathrm{HNO}_{3}$. This would likely increase the acidity of surface waters in the Neversink basin and possibly increase nitrogen concentrations in the reservoir. Water-budget data for 4 years of the project will provide baseline information that could be compared with future budget data to assess changes over time.

Information on the current status of nitrogen cycling in the Catskills is also relevant to forest-harvesting practices. Old-growth forests tend to be less productive than younger forests and therefore less efficient at immobilizing nitrogen. Timber harvesting to establish uneven-aged forests could increase nitrogen retention within the terrestrial environment and result in improved water quality; conversely, it could result in acute acidification of surface waters for 2 or 3 years until vegetation is reestablished (Lawrence and others, 1987). The effect of timber harvesting on the nitrogen cycle within the Neversink basin is being studied in detail through another USGS project being done in cooperation with the New York City Department of Environmental Protection. That project is being designed such that the results can be applied to the Neversink spatial model.

In addition to the research activities associated with the spatial model in this project, several datacollection activities will be implemented, both to support research tasks and to provide basic information on water quality and flow characteristics within the basin. A basinwide GIS data base will result from this work.

Upon completion of data collection and interpretation, results of this project will be compiled in a final report comprising interpretive discussions of each of the six research topics described herein; results of each research topic also will be published individually in a peer-reviewed scientific journal. The final report will synthesize the information from each journal article to provide a detailed description of the Neversink spatial model and will include a compilation of all data collected and will be published in a USGS interpretive series. A report detailing analytical and quality-control procedures used in this project by the Albany laboratory will be published as a USGS open-file report.

\section{REFERENCES CITED}

Aber, J.D., Nadelhoffer, K.J., Steudler, P., and Mellilo, J.M., 1989, Nitrogen saturation in northerr forest ecosystems: Bioscience, v. 39, p. 378-386.

Agren, G.I., and Bosatta, E., 1988, Nitrogen saturation of terrestrial ecosystems: Environmental Pollution, v. 54, p. 185-197.

American Public Health Association, 1981, Standard methods for examination of water and wastewater (15th ed): Washington, D.C., American P blic Health Association, unpaginated.

Armitage, P.D., Moss, D., Wright, J.F., and Furse, M.T., 1983. The performance of a new biological water quality score system based on macroinvertebrates over a wide range of unpolluted running-water sites: Water Research, v. 17, 333-347.

Baker, J.P., and Christensen, S.W., 1991. Efferts of acidification on biological communities in aquatic ecosystems, in Charles, D.F., ed., Acidic deposition and aquatic ecosystems: New York, Springer-Verlag, p. 83-106.

Baker, J.P., and Schofield, C.L., 1980, Aluminum toxicity to fish as related to acid precipitation and Adirondack surface water quality, in Drablos, D., and Tollan, A., eds., Ecological impact of acid preripitation: Oslo, Norway, SNSF Project, p. 292-293.

Baker, J.P., and Schofield, C.L., 1982, Aluminum toxicity to fish in acidic waters: Water, Air, and Soil Pollution, v. 18, p. 289-309.

Baker, J.P., and others, 1990, Biological effects of changes in surface water acid-base chemistry, National Acid Precipitation Assessment Program Report No. 13: Oak Ridge, Tenn., National Acid Precipitation Assessment Program.

Bencala, K.E., McKnight, D.M., and Zellweger, G.W., 1990, Characterization of transport in an anidic and metal-rich mountain stream based on a lith um tracer injection and simulations of transient storage: Water Resources Research, v. 26, p. 898-1000.

Bishop, K.H., Grip, H., and O'Neill, A., 1990, T'†e origins of acid runoff in a hillslope during storm events: Journal of Hydrology, v. 116, p. 35-61.

Blume, L.J., Schumacher, B.A., Schaffer, P.W., Cappo, K.A., Papp, M.L., and others, 1990, Handl rok of methods for acid deposition studies-labo-atory analyses for soil chemistry: Las Vegas, Nav., National Acid Precipitation Assessment Program, U.S. Environmental Protection Agency, Enviro nmental Monitoring Systems Laboratory, EPA/600/4-90/023.

Burns, D.A., 1989, Speciation and equilibrium relations of soluble aluminum in a headwater strean at base flow and during rain events: Water Resources Research, v. 25, p. 1653-1665. 
Casey, H., 1977, Origin and variation of nitrate nitrogen in the chalk springs, streams and rivers in Dorset and its utilization by higher plants: Progress in Water Technology, v. 8., p. 225-235.

Christensen, P.B., Nielsen, L.P., Sorensen, J., and Revsbech, N.P., 1990, Denitrification in nitrate-rich streams - diurnal and seasonal variation related to benthic oxygen metabolism: Limnology and Oceanography, v. 35, p. 640-651.

Christophersen, N., and Wright, R.F., 1981, Sulfate budget and a model for sulfate concentrations in stream water at Birkenes, a small forested catchment in southernmost Norway: Water Resources Research, v. 17, p. 377-389.

Christophersen, N., Neal, C., Hooper, R.P., Vogt, R.D., and Andersen, S., 1990, Modelling stream-water chemistry as a mixture of soilwater end-members-a step towards second-generation acidification models: Journal of Hydrology, v. 116, p. 307-320.

CLEAR (Cornell University Laboratory for Environmental Applications of Remote Sensing), 1988, New York State Land Use and Natural Resources Inventory - Classification Manual, $48 \mathrm{p}$.

Cleveland, L., Little, E.E., Hamilton, S.J., Buckler, D.R., and Hunn, J.B., 1986, Interactive toxicity of aluminum and acidity to early life stages of brook trout: Transactions of the American Fisheries Society, v. 115, p. 610-620.

Colquhoun, J., Kretser, W., and Pfeiffer, M., 1984, Acidity Status Update of Lakes and Streams in New York State: New York State Department of Environmental Conservation, No. WM P-83 (6/84).

Cosby, B.J., Hornberger, G.M., and Galloway, J.N., 1985, Modeling the effects of acid deposition-Assessment of a lumped parameter model of soil water and stream-water chemistry: Water Resources Research, v. 21, p. 51-63.

David, M.B., and Driscoll, C.T., 1984, Aluminum speciation and equilibria in soil solutions of a Haplorthod in the Adirondack Mountains (New York): Geoderma, v. 33, p. 297-318.

David, M.B., Fuller, R.D., Fernandez, I.J., Mitchell, M.J., Rustad, L.E., Vance, G.F., Stam, A.C., and Nodvin, S.C., 1990, Spodosol variability and assessment of response to acidic deposition: Soil Science Society of America Journal, v. 54, p. 541-548.

Daye, P.G., and Garside, E.T., 1976, Histopathologic changes in surficial tissues of brook trout, Salvelinus fontinalis (Mitchell), exposed to acute and chronic levels of pH: Canadian Journal of Zoology, v. 54, p. $2140-2155$.

DeWalle, D.R., Swistock, B.R., and Sharpe, W.E., 1988, Three-component tracer model for stormflow on a small Appalachian forested catchment: Journal of Hydrology, v. 104, p. 301-310.
Driscoll, C.T., Baker, J.P., Bisogni, J.J., and Schofield, C.L., 1980, Effect of aluminum speciation on fish in dilute acidified waters: Science, v. 284, p. 161-164.

Driscoll, C.T., Johnson, N.M., Likens, G.E., and Feller, M.C., 1988, Effects of acidic deposition on the chemistry of headwater streams-A comparison between Hubbard Brook, New Hampshire, and Jamieson Creek, British Columbia: Water Resour'es Research, v. 24, p. 195-200.

Driscoll, C.T., Likens, G.E., Hedin, L.O., Eainn, J.S., and Bormann, F.H., 1989, Changes in the ch?mistry of surface waters-25-year results of the Hubbard Brook Experimental Forest, N.H.: Envi-onmental Science and Technology, v. 23, p. 137-142.

Ethridge, 1977, Petrology, transport, and environment in isochronous Upper Devonian sandstone and siltstone units, New York: Journal of Sedimentary Petrology, v. 47, p. 53-65.

Fishman, M.J., and Friedman, L.C., 1989, Methods for determination of inorganic substances ir water and fluvial sediments: U.S. Geological Survi.y Techniques of Water Resources Investigatiors, book 5, chap. A1, 545 p.

Gagen, C.J., and Sharpe, W.E., 1987, Influence of acid runoff episodes on survival and net sodium balance of Brook Trout (Salvelinus fontinalis) confined in a mountain stream, in Witters, H., and Vanderborght, O., eds., Ecophysiology of acid stress in aquatic organisms: Antwerp, Belgium, Societe Poyale Zoologique De Belgique, p. 219-230.

Gebert, W.A., Gracyk, D.J., and Krug, W.R.. 1985, Average annual runoff in the United States, 1051-80: U.S. Geological Survey Open-File Report 85-627, scale 1:2,000,000, $506 \mathrm{p}$.

Gherini, S.A. Mok, L., Hudson, R.J.M., Davis, G.F., Chen, C.W, and Goldstein, R.A., 1985, The ILWAS model-formulation and application: V/ater, Air, and Soil Pollution, v. 26, p. 95-113.

Gran, G., 1952, Determination of the equivalence point in potentiometric titrations: International Congress of Analytical Chemists, v. 77, p. 661-667.

Hall, R.J., Driscoll, C.T., and Likens, G.E., 1987, Importance of hydrogen ions and aluminum in regulating the structure and function of stream ecorystems-an experimental test: Freshwater Biology, v. 18, p. $17-43$.

Hall, R.J., Likens, G.E., Fiance, S.B., and Hendrey, G.R., 1980, Experimental acidification of a st ${ }^{-e}$ eam in the Hubbard Experimental Forest, New Hampshire: Ecology, v. 61, p. 976-989.

Havas, M., 1981, Physiological response of aquatic animals to low pH, in Singer, R., ed., Effects of acid precipitation on benthos: Hamilton, N.Y., North American Benthological Society, p. 49-55. 
Henriksen, A., Skogheim, O.G., and Rosseland, B.O., 1984, Episodic changes in $\mathrm{pH}$ and aluminum-speciation kill fish in a Norwegian salmon river: Vatten, v. 40 , p. $255-260$.

Henriksen, A., Wathne, B.M., Rogeberg, E.J.S., Norton, S.A., and Brakke, D.F., 1988, The role of stream substrates in aluminum mobility and acid neutralization: Water Research, v. 22, p. 1069-1073.

Hicks, B.B., 1986, Measuring dry deposition-A reassessment of the state of the art: Water, Air and Soil Pollution, v. 30, p. 75-90.

Hill, A.R., 1981, Nitrate-nitrogen flux and utilization in a stream ecosystem during low summer flows: Canadian Geographer, v. 25, p. 225-239.

Hooper, R.P., Christophersen, N., and Peters, N.E., 1990, Modelling stream-water chemistry as a mixture of soilwater end-members - an application to the Panola Mountain catchment, Georgia, U.S.A.: Journal of Hydrology, v. 116, p. 321-343.

Hubbard, E.F., 1992, Policy recommendations for management and retention of hydrologic data of the U.S. Geological Survey: U.S. Geological Survey OpenFile Report 92-56, 32 p.

Huntington, T.G., Ryan, D.F., and Hamburg, S.P., 1988, Estimating soil nitrogen and carbon pools in a northern hardwood forest ecosystem: Soil Science Society of America Journal, v. 52, p. 1162-1167.

Ingersoll, C.G., Mount, D.R. Gulley, D.D., LaPoint, T.W., and Bergman, H.L., 1988, Effects of pH, aluminum, and calcium on survival and growth of eggs and fry of brook trout (Salvelinus fontinalis): Canadian Journal of Fisheries and Aquatic Sciences, v. 47, p. 1580-1592.

Iorio, A.L., 1972, Precipitation regimes of the Upper Delaware basin and Catskill Region: Albany, N.Y., Upper Delaware River Regional Resources Planning Board and New York State Department of Environmental Conservation, Office of Water Management and Planning.

Jirka, A.M., Carter, M.J., May, D., Fuller, F.D., 1976, New survey method of total N: Environmental Science and Technology, v. 110, p. 1038-1044.

Johnson, D.W., Simonin, H.A., Colquhoun, J.R., and Flack, F.M, 1987, In situ toxicity tests of fishes in acid waters: Biogeochemistry, v. 3, p. 181-208.

Johnson, N.M., Driscoll, C.T., Eagon, J.S., Likens, G.E., and McDowell, W.H., 1981, Acid rain, dissolved aluminum and chemical weathering at the Hubbard Brook Experimental Forest, New Hampshire: Geochemica et Cosmochimica Acta, v. 45, p. 1421-1437.

Johnson, N.M., Likens, G.E., Bormann, F.H., Fisher, D.W., and Pierce, R.S., 1969, A working model for the variation in stream-water chemistry at the Hubbard Brook Experiment Forest, New Hampshire:
Water Resources Research, v. 5, p. 1353-1663.

Karr, J.R., Fausch, K.D., Angermeier, P.L., Yant, P.R., and Schlosser, I.J., 1986, Assessing biologrical integrity in running waters, a method and its rationale: Champaign, Ill., Illinois Natural History Survey, Special Publication No. 5.

Kaushik, N.K., Robinson, J.B., Sain, P., Whitr'ey, H.R., and Stammers, W.N., 1975, A quantitative study of nitrogen loss from water of a small spring-fed stream: Proceedings of the Canadian Symposium on Water Pollution Research, v. 10, p. 110-117.

Kudish, M., 1979, Catskill soils and forest history: Hobart, N.Y., Catskill Center for Conservation, 45 p.

Lawrence, G.B., and Driscoll, C.T., 1988, Aluminum chemistry downstream of a whole-tree-harvested watershed: Environmental Science and Terhnology, v. 22 , p. $1293-1299$.

1990, Longitudinal patterns of concentration-discharge relationships in stream water drain'ng the Hubbard Brook Experimental Forest, New' Hampshire: Journal of Hydrology, v. 116, p. 147-165.

Lawrence, G.B., and Fernandez, I.J., 1991, Biogeohemical interactions between acidic deposition and a lowelevation spruce-fir stand in Howland, Mc ne: Canadian Journal of Forest Resources, v. 21, p. 867-875.

Lawrence, G.B., Driscoll, C.T., and Fuller, R.D., 1986, Spatial relationships of aluminum chemistry in the streams of the Hubbard Brook Experimental Forest: Biogeochemistry, v. 2, p. 115-135.

Lawrence, G.B., Fuller, R.D., and Driscoll, C.T., 1987, Release of aluminum following whole-tre : harvesting at the Hubbard Brook Experimental Forest, New Hampshire: Journal of Environmental Qurlity, v. 16, p. 383-390.

Leivestad, H., 1981, Physiological effects of a :id stress on fish, in Haines, T.A., and Johnson, R.E., eds., in Acid Rain/Fisheries-Proceedings of an International Symposium on Acidic Rain and Fishery Impacts on Northeastem North America: Ithaca, N.Y.,Comell University, American Fisheries Society, p. 157-164.

Likens, G.E., Bormann, F.H., Pierce, R.S., Earon, J.S., and Johnson, N.M., 1977, Biogeochemistry of a forested ecosystem: New York, Springer-Ve-lag, 146 p.

Lindberg, S.E., 1992, Atmospheric deposition and canopy interactions of sulfur, in Johnson, D.W., and Lindberg, S.E., eds., Atmospheric deposition and nutrient cycling in forest ecosystems: New York, SpringerVerlag, section 5.2.

Lindberg, S.E., and Garten, C.T., 1988, Sources of sulfur in forest canopy throughfall: Nature, v. 336, p. $148-151$. 
Lovett, G.M., 1992, Atmospheric deposition and canopy interactions of nitrogen, in Johnson, D.W., and Lindberg, S.E., eds., Atmospheric deposition and nutrient cycling in forest ecosystems: New York, SpringerVerlag, section 6.2.

Lovett, G.M., and Kinsman, J.D., 1990, Atmospheric pollutant deposition to high-elevation ecosystems: Atmospheric Environment, v. 24A, p. 2767-2786.

McAvoy, D.C., 1989, Episodic response of aluminum chemistry in an acid-sensitive Massachusetts catchment: Water Resources Research, v. 25, p. 233-240.

McKeague, J.A., Brydon, J.E., and Miles, N.M., 1971, Differentiation of forms of extractable iron and aluminum in soils: Soil Science Society of America Proceedings, v. 35, p. 33-38.

McKnight, D.M., and Feder, G.L., 1984, The ecological effect of acid conditions and precipitation of hydrous metal oxides in a Rocky Mountain stream: Hydrobiologia, v. 119, p. 129-138.

Mount, D.R., Ingersoll, C.G., Gulley, D.D., Fernandez, J.D., LaPoint, T.W., and Bergman, H.L., 1988, Effect of long-term exposure to acid, aluminum, and low calcium on adult brook trout (Salvelinus fontinalis). 1. Survival, growth, fecundity, and progeny survival: Canadian Journal of Aquatic Sciences, v. 45, p. 16231632.

Murdoch, P.S., and Stoddard, J.L., 1992, The role of nitrate in the acidification of streams in the Catskill Mountains of New York: Water Resources Research, v. 28, p. 2707-2720.

1993, Chemical characteristics and temporal trends in eight streams of the Catskill Mountains, New York: Water, Air, and Soil Pollution, v. 67, p. 367-395.

Murdoch, P.S., Bonitz, C.E., Eakin, K.W., Ranalli, A.J., and Witt, E.C., 1990, Episodic acidification and associated fish and aquatic invertebrate responses in four Catskill Mountain streams-An interim report of the Episodic Response Project: U.S. Geological Survey Open-File Report 90-566, 50 p.

National Oceanic and Atmospheric Administration, 1990 , Climatological Data-Annual Summary New York: Asheville, N.C., National Climatic Data Center, v. $102,39 \mathrm{p}$.

Nelson, D.W., and Summers, L.E., 1982, Total carbon, organic carbon, and organic matter, in Page, A.L., ed., Methods of soil analysis, part 2, second ed.: Agronomy, v. 9, p. 539-579.

Nordstrom, D.K., and Ball, J.W., 1986, The geochemical behavior of aluminum in acidified surface waters: Science, v. 232, p. 54-56.

Norton, S.A., and Henriksen, A., 1983, The importance of carbon dioxide in evaluation of effects of acidic deposition: Vatten, v. 39, p. 346-354.
Okland, K.A., and Okland, J., 1986, The effects of acid deposition on benthic animals in lakes ant streams: Experientia, v. 42, p. 471-486.

Packer, R.K., 1979, Acid-base balance and gas exchange in brook trout (Salvelinus fontinalis) expred to acid environments: Journal of Experimental Piology, v. 79 , p. 127-134.

Packer, R.K, and Dunson, W.A., 1972, Anox' and sodium loss associated with the death of brock trout at low $\mathrm{pH}$ : Comparative Biochemistry and Physiology, v. 41A, p. 17-26.

Parker, G.G., Hely, A.G., Keighton, W.B., O'nstead, F.H., and others, 1964, Water resources of the Delaware River basin: U.S. Geological Survey Professional Paper 381, $200 \mathrm{p}$.

Parkhurst, B.J., 1987, A comparison of laboritory and in situ bioassays for evaluating the toxicity of acidic waters to brook trout: Ph.D. thesis, Laramie, Wy., University of Wyoming, $124 \mathrm{p}$.

Peden, M.E., and others, 1986, Development of standard methods for the collection and analysis of precipitation: Illinois State Water Survey, ISWS Contract Report 381.

Pinder, G.F., and Jones, 1969, J.F., Determinntion of the ground-water component of peak discharge from the chemistry of total runoff: Water Resources Research, v. 5, p. 438-445.

Powers, E.B., 1929, The relative temperature, oxygen content, alkali reserve, the carbon dioxid? tension and $\mathrm{pH}$ of the waters of certain mountair streams at different altitudes in the Smoky Mountain National Park: Ecology, v. 10, p. 97-110.

Pratt, J.M., and Hall, R.J., 1981, Acute effects of stream acidification on the diversity of stream invertebrate drift, in Singer, R., ed., Effects of acid precipitation on benthos: Hamilton, N.Y., North American Benthological Society, p. 77-95.

Raleigh, R.F., 1982, Habitat suitability index models brook trout: U.S. Fish and Wildlife Service, FWS/ OBS-82/10.24, $42 \mathrm{p}$.

Raddum, G.G., 1980, Comparison of benthic invertebrates in lakes with different acidity, in Drablos, D., and Tollan, A. (ed.), Ecological impact $c^{f}$ acid precipitation: Oslo, Norway, SNSF Project. p. 330-331.

Raddum, G.G., and Fjellheim, A., 1984, Acidification and early warning organisms in freshwater in westem Norway: International Association of TT-eoretical and Applied Limnology Proceedings, v. 22, p. 19731980.

Rantz, S.E., and others, 1982, Measurement and computation of streamflow: U.S. Geological Survey Water Supply Paper 2175 [ 2 v.], 631 p.

Rich, J.L., 1934, Glacial geology of the Catskills: New York State Museum Bulletin 299, 180 p. 
Robinson, J.B., Whitely, H.R., Stammers, W., Kaushik, N.K., and Sain, P., 1979, The fate of nitrate in small streams and its management implications, in Lohr, R.C., and others, eds., Best management practices for agriculture and silviculture: Ann Arbor, Mich., Ann Arbor Science, p. 247-259.

Schecher, W.D., and Driscoll, C.T., 1987, An evaluation of uncertainty associated with aluminum equilibrium calculations: Water Resources Research, v. 23, p. 525-534.

Schofield, C.L., and Driscoll, C.T., 1987, Fish species distribution in relation to water quality gradients in the North Branch of the Moose River Basin: Biogeochemistry, v. 3., p. 63-85.

Schofield, C.L., and Trojnar, J.R., ed., 1980, Aluminum toxicity to Brook Trout (Salvelinus fontinalis) in acidified waters: New York, Plenum Press, p. 341366.

Skeffington, R.A., and Wilson, E.J., 1988, Excess nitrogen deposition-Issues for consideration: Environmental Pollution, v. 54, p. 159-184.

Stoddard, J.L., 1991, Trends in Catskill stream water quality - evidence from historical data: Water Resources Research, v. 27, p. 2855-2864.

Stoddard, J.L., and Murdoch, P.S., 1991, Catskill Mountains, in Charles, D.F., ed., Acidic deposition and aquatic ecosystems - regional cases studies: New York, Springer-Verlag, p. 237-271.

Tabatabai, M.A., and Dick, W.A., 1983, Simultaneous determination of nitrate, chloride, sulfate and phosphate in natural waters by ion chromatography: Journal of Environmental Quality, v. 12, p. 209-213.

Theobald, P.K., Lakin, H.W., and Hawkins, D.B., 1963, The precipitation of aluminum, iron, and manganese at the junction of Deer Creek with the Snake River in Summit County, Colorado: Geochemica et Cosmochimica Acta, v. 27, p. 121-132.

Tornes, L.A., 1979, Soil survey of Ulster County, New York: U.S. Department of Agriculture, Soil Conservation Service, 273 p.
Triska, F.J., Duff, J.H., and Avanzino, R.J., 19?0a, Influence of exchange flow between the chann ${ }^{\prime}$ and hyphoreic zone on nitrate production in a sm?ll mountain stream: Canadian Journal of Fisheries and Aquatic Sciences, v. 47, p. 2099-2111.

Triska, F.J., Kennedy, V.C., Avanzino, R.J., Zellweger, G.W., Bencala, K.E., 1990b, In situ retention-transport response to nitrate loading and storm discharge in a third order stream: Journal of the North American Benthological Society, v. 9, p. 229-239.

Turner, M.G., and Gardner, R.H., 1990, Quant : tative methods in landscape ecology: New York. SpringerVerlag, $536 \mathrm{p}$.

U.S. Environmental Protection Agency, 1987, Handbook of methods for acid deposition studies-Laboratory Analysis for Surface Water Chemistry: USEPA 600/ 4-87/026.

van Breemen, N., Mulder, J., and Driscoll, C.T., 1982, Acidification and alkalinization of soils: F'ant and Soil, v. 75, p. 283-308.

Van Kessel, J.F., 1977, Removal of nitrate from effluent following discharge on surface water: Water Research, v. 11, p. 533-537.

Way, J.H., 1972, A more detailed discussion of the depositional environmental analysis-middle and upper Devonian sedimentary rocks, Catskill Mountain area, New York: Rensselaer Polytechnic Institute, Troy, N.Y., unpublished Ph.D. dissertation, 145 p.

Wolock, D.M., Hornberger, G.M., and Musgrc"e, T.J., 1990, Topographic effects on flow path an 4 surface water chemistry of the LLyn Brianne catcl nents in Wales: Journal of Hydrology, v. 115, p. 243-259.

Wood, E.F., Sivapalan, M., Beven, K., and Band, L., 1988 , Effects of spatial variability and scale with implications to hydrologic modeling: Journal of Hydrology, v. 102, p. 29-47.

Zippin, C., 1958, The removal method of population estimation: Journal of Wildlife Management, v. 22, p. 82-90. 


\section{Appendixes}

1. Field Implementation Schedule. . . . . . . . . 32

2. Analytical Methods . ........................ 36

3. Quality Assurance Plan for Streamflow Measurements . . . . . . . . . . 40

4. Data management $\ldots \ldots \ldots \ldots \ldots \ldots \ldots \ldots \ldots \ldots \ldots \ldots \ldots \ldots \ldots \ldots \ldots$ 


\section{APPENDIX 1: FIELD IMPLEMENTATION SCHEDULE}

\section{TOPIC A: SMALL (FIRST-ORDER) WATERSHEDS}

\section{Work Element 1.-Subsurface-Water Residence Time}

1. Installation of a headwater streamflow-gaging station.

2. Biweekly stream-water collection at 8 locations upstream of gage.

3. Periodic sets of streamflow measurements taken at all 8 sampling sites.

4. Identification of seep collection points along an elevated gradient.

5. Periodic seep-water collection.

6. Installation of weighing-bucket rain gage.

7. Installation of 70 throughfall collectors, 5 collectors per plot, at 14 elevations in Winnisook watershed.

8. Precipitation and stream-water sampling before, during, and after three selected storms.

Work Element 2.-Hillslope Gradients of Soil Chemistry

1. Insertion of about 130 mineral-soil bags along an elevational gradient in Winnisook Watershed.

2. Collection and chemical analysis of about $200 \mathrm{Oa}$ and Bs horizon soil samples along an elevational gradient in a Winnisook watershed.

3. Collection and chemical analysis of mineral soil bags.
April 1991

June 1991

April 1992

November 1993

April 1992

July 1992

May 1992

May 1994

April 1992

June 1992

April 1992

November 1992

May 1992

November 1993

May 1994

May 1995

May 1993

December 1993

August 1995

Work Element 3.-Extrapolation of Relations to Other First-Order Watersheds

1. Stream-water sampling along elevational gradients of about 15 first-order streams.

2. Installation of a streamflow-measurement gage in a firstorder watershed remote from Winnisook Watershed.

3. Stream-water sampling along elevational gradients of five first-order watersheds (including the gaged watershed of activity 2 , representative of the Neversink River basin. Streams will be sampled at low and high flows.

4. Sampling of 20 first-order streams at locations just upstream from the confluence of the first adjoining stream. Each of the April 1993 August 1994

20 streams will be sampled at low and high flows .

November 1991 November 1992

June 1992

July 1991

July 1992

June 1994 


\section{TOPIC B: INTERMEDIATE AND LARGE WATERSHEDS}

Work Element 1.-Spatial Controls at Intermediate and Large Scales

1. Installation of 5 streamflow gages in intermediate and large watersheds.

2. Biweekly stream-water sampling at all streamflow gages.

3. Biweekly stream-water sampling along an elevational gradient of a stream that increases in drainage area from first order to sixth order.

4. Streamflow measurements at ungaged locations to evaluate tributary effects on chemical transport.

5. Streamwater sampling along elevational gradients of two additional gaged, intermediate-sized watersheds at high, April 1991 June 1991 intermediate, and low streamflows (3 sampling dates).

June 1991

June $19 ? 4$

June 1991

July 19 ?

April 1993

Octobe- 1994

November 1991

October 1994

Work Element 2.-Effect of Watershed Size on Temporal Variations in Stream Chemistry

1. Stage-activated automated stream-water sampling at five streamflow-gaging stations during high flows in the spring

April 1992

April 1994 and fall.

2. Continuous field $\mathrm{pH}$ measurements in a first-order watershed and near the Neversink Reservoir.

3. Stream-water sampling for suspended-solids analysis in the Neversink River above the reservoir.

June 1992

September 1993

April 1992

April 1995

\section{TOPIC C: LANDSCAPE CONTROLS ON STREAM CHEMISTRY}

Work Element 1.-Identifying the Effects of Landscape on Neversink River Water Quality

1. Stream-water survey sampling to identify four distinct types of landscape for landscape plot studies.

2. Streamflow measurements on stream reaches affected by hemlock stands.

3. Bimonthly seep-water sampling at approximate sites within landscape plots.

November $1991 \quad$ Noven ber 1992

April $1992 \quad$ May 1994

April $1992 \quad$ Septen ber 1994

4. Biweekly sampling of 10 seeps and 5 stream sites to determine subsurface water residence time.

October $1993 \quad$ September 1994

Work Element 2.-Modeling the Sources of Landscape Effects on Stream-Water Quality

1. Installation of Oa- and Bs-horizon soil lysimeters, seepage

November $1991 \quad$ Noverr ber 1993 collectors, and shallow ground-water samplers as needed to sample end members for each type of landscape.

2. End-member sampling for EMMA model analysis (soil solutions, shallow ground water, and seep water, collected seasonally to monthly).

3. End-member sampling at locations within the same landscape plots, to test the EMMA model. 


\section{TOPIC D: NONCONSERVATIVE TRANSPORT OF NITRATE AND ALUMINUM IN STREAM WATER}

\section{Work Element 1.-Nitrate}

1. Reconnaissance stream-water sampling for site selection.

2. Installation of wells, 2 per site.

3. Stream-reach mass-balance measurements: collection of 24 stream-water samples and 6 ground-water samples, with flow measurements over a 24-hour period, four times (early spring, late spring, midsummer, and late fall).

4. Chemical tracer experiments: collection of 36 stream-water and 12 ground-water samples, with flow measurements over a 2- to 5-day period in each of the two experimental stream reaches, in midsummer and late fall.

Work Element 2.-Aluminum

1. Reconnaissance stream-water sampling for site selection.

2. Monthly stream-water sampling of 1 of the experimental reaches, four samples per month.

3. Stream-reach aluminum speciation measurements, collection of 48 stream-water samples and flow measurements, over about 30 days in early spring, midsummer, and late fall.

4. Placement of mesh bags of homogeneous sediment in the stream to evaluate precipitation/ dissolution in reaches where disequilibrium conditions occur.

\section{TOPIC E: NITROGEN CYCLING}

\section{Work Element 1.-Quantifying Nitrogen Budgets}

1. Installation of 80 throughfall collectors in Winnisook watershed

2. Throughfall collections biweekly during spring, summer, and fall; monthly in winter

3. Installation of wet-only precipitation collectors at two locations in Winnisook watershed.

4. Installation of one 5-m atmospheric-depositionmonitoring tower at the base of Winnisook watershed.

5. Sampling of wet-only precipitation collection.

6. Air-quality and meteorological measurements from the tower.

7. Monthly stream-water sampling for analysis of total nitrogen concentration at the gaging station (analysis could be discontinued if results indicate low concentrations).

8. Streamflow sampling at the gaging station during storms for 1 month in spring and fall. Chemical analysis will include total nitrogen.
September 1991

May 1992

April 1992

June 1992

September 1993

September 1992

October 1994

September 1991

November 1991

March 1992

November 1993

July 1992

August 1993

August 1993

May 1994

September 1992

April 1993

May 1993

September 1995

May 1993

May 1993

May 1992

August 1993

June 1993

September 1995

August 1993

February 1992

September 1995

June 1995

April 1992

April 1995 


\section{TOPIC F: WATER QUALITY AND AQUATIC BIOLOGICAL COMMUNITIES}

\section{Work Element 1.-Aquatic Toxicity}

1. Thirty-day onsite fish bioassays at nine sites, run once in spring, summer, and fall.

October 1992 June 19:4

Work Element 2.-Integrity of Biological Communities

1. Fish shocking at $\mathbf{1 0}$ sites once per year, and at five sites three times times per year. Streamflow measurements will be July 1991 June $19: 4$ taken, and one stream-water sample collected at each sitefor complete chemical analysis, on each shocking date.

2. Start of aquatic-invertebrate sampling at 10 sites once per year, and at three sites four times per year. 


\section{APPENDIX 2: ANALYTICAL METHODS}

\section{TABLES}

2A. Analytical procedures used to measured concentrations of major solutes. . . . . . . . 37

2B. Reporting limits and data quality objectives for accuracy, precision, and blanks . . . . . . 38

2C. Analytical procedures for soil chemistry analysis . . . . . . . . . . . . . . . . . 39

2D. Data-quality objectives for accuracy and precision of soil analyses . . . . . . . . . . 39 


\section{APPENDIX 2: ANALYTICAL METHODS}

Solutions collected during this project will include precipitation, throughfall, soil water, ground water, seepage, and stream water. These will be analyzed for all major solutes at the USGS Water Analysis Laboratory in Albany, N.Y. The list of major solutes and the methods used to measure their concentrations are given in table 2A. Quality-assurance procedures used at the Albany laboratory are similar to those used by the U.S. Environmental Protection Agency for analysis of surface waters in acid-deposition studies (U.S. Environmental Protection Agency, 1987). Data-quality objectives and reporting limits for analyses performed in the Albany laboratory are given in table 2B. A report detailing analysis and quality-assurance procedures for the Albany laboratory in this project will be compiled, as will annual summaries of quality- assurance data.

Analysis of suspended-solids samples for total nitrogen and total phosphorus concentrations will be done by the USGS National Laboratory in Denver, Colo. Total nitrogen and total phosphoris concentrations will be measured by the Jirka method, a modified Kjeldahl block digestion folloved by colorimetric detection (Jirka and others, 1976; Patton and Truitt, 1992). Selected precipitation, throughfall, seepage, and stream-water samples will also be analyzed for ${ }^{18} \mathrm{O} /{ }^{16} \mathrm{O}$ ratios through mass spectrometry at the USGS Isotope Labor'tory in Reston, Va.

Analysis of soil samples and miner l-soil bags will be done by a contracting laboratory yet to be determined. Criteria for laboratory selec ${ }^{+}$ion will include the requirement that analyses be done according to USEPA methods (Blume and others, 1990). All analyses will be done on air-dried soils that have passed through a 2-mm-mesh sieve and meet dataquality objectives listed in table $2 \mathrm{C}$.

Table 2A. Analytical procedures used to measure concentrations of major solutes.

\begin{tabular}{|c|c|c|}
\hline Constituent or Property & Method & Reference \\
\hline $\mathrm{SO}_{4}^{2-}, \mathrm{NO}_{3}^{-}, \mathrm{Cl}^{-}$ & Ion chromatography & Tabatabai and Dick, 1983 \\
\hline $\mathrm{pH}$ & Potentiometric & Peden and others, 1986 \\
\hline $\mathrm{Ca}^{2+}, \mathrm{Mg}^{2+}$ & Atomic absorption spectrophotometry & Fishman and Friedman, 1989 \\
\hline $\mathrm{Si}$ & Automated heteropoly blue colorimetry & $\begin{array}{l}\text { American Public Health Assn- } \\
\text { ciation, } 1981\end{array}$ \\
\hline $\mathrm{Na}^{+}, \mathrm{K}^{+}$ & Atomic emission spectrophotometry & Fishman and Friedman, 1989 \\
\hline $\mathrm{NH}_{4}^{+}$ & $\begin{array}{l}\text { Automated flow-injection colorimetric } \\
\text { phenate }\end{array}$ & $\begin{array}{l}\text { American Public Health Assn- } \\
\text { ciation, } 1981\end{array}$ \\
\hline Dissolved organic carbon & Filtration, total carbon analyzer & $\begin{array}{l}\text { U.S. Environmental Protection } \\
\text { Agency, } 1987\end{array}$ \\
\hline Total aluminum & Atomic absorption graphite furnace & Fishman and Friedman, 198? \\
\hline Total monomeric Al & $\begin{array}{l}\text { Automated flow injection pyrocatechol } \\
\text { colorimetry }\end{array}$ & Peden and others, 1986 \\
\hline Organic monomeric $\mathrm{Al}$ & $\begin{array}{l}\text { Automated flow injection ion exchange, } \\
\text { pyrocatechol colorimetry }\end{array}$ & Peden and others, 1986 \\
\hline Total F & Ion selective electrode & $\begin{array}{l}\text { U.S. Environmental Protection } \\
\text { Agency, } 1987\end{array}$ \\
\hline Acid-neutralizing capacity & Strong acid titration & Gran, 1952 \\
\hline
\end{tabular}


Table 2B. Reporting limits and data-quality objectives for accuracy, precision, and blanks for s?lution analyses performed by the U.S. Geological Survey laboratory in Albany, N.Y.

[ DQO, data-quality objective. $\mu \mathrm{mol} / \mathrm{h}$, micromoles per liter. $\mathrm{cv}$, coefficient of variation. ANC, acid-neutralizing capacity. Numbers in "dividing value" column are concentrations that divide high range from low range of precision DQO's. pH and ANC values (in parentheses) are in $\mathrm{pH}$ units and microequivalents per liter, respectively. ]

\begin{tabular}{|c|c|c|c|c|c|c|c|c|c|}
\hline \multirow[b]{3}{*}{$\begin{array}{l}\text { Constituent or } \\
\text { property }\end{array}$} & \multirow[b]{3}{*}{$\begin{array}{l}\text { Report- } \\
\text { ing limit } \\
\text { ( } \mu \text { mol/L) }\end{array}$} & \multicolumn{4}{|c|}{ Accuracy } & \multicolumn{3}{|c|}{ Precision } & \multirow{3}{*}{$\begin{array}{c}\text { Filter and } \\
\text { analysis } \\
\text { blanks } \\
\mathrm{DOO} \\
(\mu \mathrm{mo} / \mathrm{L})\end{array}$} \\
\hline & & \multicolumn{2}{|c|}{$\begin{array}{l}\text { Low-concentration } \\
\text { quality-control sample }\end{array}$} & \multicolumn{2}{|c|}{$\begin{array}{l}\text { High-concentration } \\
\text { quality-control sample }\end{array}$} & \multirow{2}{*}{$\begin{array}{l}\text { Low-con- } \\
\text { centration } \\
\text { range } \\
\text { DQO } \\
\text { (cv) }\end{array}$} & \multirow[b]{2}{*}{ 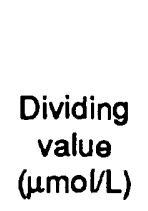 } & \multirow{2}{*}{$\begin{array}{l}\text { High-con- } \\
\text { centration } \\
\text { range } \\
\text { DQO } \\
\text { (cv) }\end{array}$} & \\
\hline & & $\begin{array}{c}\text { DQO } \\
\text { (percent } \\
\text { error) }\end{array}$ & $\begin{array}{c}\text { Concen- } \\
\text { tration } \\
(\mu \mathrm{mol} / \mathrm{L})\end{array}$ & $\begin{array}{l}\text { DQO } \\
\text { (percent } \\
\text { error) }\end{array}$ & $\begin{array}{c}\text { Concen- } \\
\text { tration } \\
(\mu \mathrm{mol} / \Omega)\end{array}$ & & & & \\
\hline$\overline{\mathrm{Br}}$ & 2.0 & 10 & 20 & 10 & 150 & 15 & 8 & 10 & 0.5 \\
\hline $\mathrm{Cl}^{-}$ & 2.0 & 10 & 8.5 & 10 & 85 & 15 & 8 & 10 & 0.5 \\
\hline $\mathrm{NO}_{3}^{-}$ & 2.0 & 10 & 5 & 10 & 50 & 15 & 5 & 10 & 0.3 \\
\hline $\mathrm{SO}_{4}^{2-}$ & 2.0 & 10 & 8.3 & 10 & 83 & 15 & 8.3 & 10 & 0.3 \\
\hline $\mathrm{Ca}^{2+}$ & 2.0 & 10 & 25 & 10 & 100 & 15 & 10 & 10 & 1.0 \\
\hline $\mathrm{Mg}^{2+}$ & 1.0 & 10 & 8.2 & 10 & 33 & 15 & 5 & 10 & 0.5 \\
\hline $\mathrm{Na}^{+}$ & 1.0 & 10 & 8.7 & 10 & 35 & 15 & 15 & 10 & 1.0 \\
\hline $\mathrm{K}^{+}$ & 1.0 & 10 & 5.1 & 10 & 20 & 15 & 5 & 10 & 0.5 \\
\hline $\mathrm{NH}_{4}^{+}$ & 2.0 & 15 & 7.1 & 10 & 17.5 & 15 & 5 & 10 & 1.0 \\
\hline Total Al & 1.0 & 15 & 1.8 & 10 & 28 & 15 & 1 & 5 & 0.5 \\
\hline $\begin{array}{l}\text { Total mono- } \\
\text { meric Al }\end{array}$ & 1.5 & 10 & 7.4 & 10 & 18.5 & 15 & 5 & 10 & 0.75 \\
\hline $\begin{array}{l}\text { *Organic } \\
\text { monomeric } \mathrm{Al}\end{array}$ & 1.5 & -- & -- & -- & -- & 15 & 5 & 10 & 0.75 \\
\hline Total Si & 6.0 & 15 & 35.6 & 10 & 107 & 15 & 50 & 10 & 3 \\
\hline $\begin{array}{l}\dagger \text { Dissolved } \\
\text { organic carbon }\end{array}$ & 41.0 & 15 & 83 & 10 & 415 & 15 & 83 & 10 & 18 \\
\hline Total F & 0.5 & 10 & 2.0 & 10 & 10.0 & 15 & 1.5 & 10 & 0.2 \\
\hline$\ddagger \mathrm{pH}$ & -- & 10 & $(4.41)$ & 20 & (6.88) & 10 & $(6.00)$ & 20 & -- \\
\hline$\ddagger \mathrm{ANC}$ & -- & 10 & $(-39.9)$ & 10 & (125) & 10 & -- & 10 & -- \\
\hline
\end{tabular}

* Quality-control samples for organic monomeric $\mathrm{Al}$ are unavailable.

$\uparrow$ Dissolved organic carbon concentrations are expressed as $\mu \mathrm{mol} \mathrm{C} / \mathrm{L}$.

$\ddagger \mathrm{pH}$ : Values in parentheses are standard $\mathrm{pH}$ units. Percent error and coefficient of variation determined from $\left[\mathrm{H}^{+}\right]$. Blanks not run for $\mathrm{pH}$.

ANC: Values in parentheses are in microequivalents per liter. For values within \pm 20 microequivalents per liter, an absolute data-quality objective of \pm 6 microequivalents per liter is used for precision, rather than a coefficient of variation of 10 for values outside this range. Blanks not run for ANC. 
Table 2C. Analytical procedures for soil-chemistry analysis.

\begin{tabular}{|c|c|c|}
\hline Constituent or Property & Method & Reference \\
\hline $\mathrm{H}_{2} \mathrm{O}$ - and $\mathrm{CaCl}$-exchangeable $\mathrm{pH}$ & Potentiometric & Blume and others, 1990 \\
\hline Exchangeable $\mathrm{Ca}^{2+}, \mathrm{Mg}^{2+}, \mathrm{Na}^{+}, \mathrm{K}^{+}, \mathrm{Al}$ & $\begin{array}{l}\text { Atomic absorption spectro } \\
\text { photometry }\end{array}$ & Blume and others, 1990 \\
\hline Exchangeable acidity & Strong-acid titration & Blume and others, 1990 \\
\hline Total carbon & LECO carbon analyzer & Nelson and Summers, 1982 \\
\hline Total nitrogen & $\begin{array}{l}\text { Kjeldahl digestion, automated } \\
\text { phenate }\end{array}$ & $\begin{array}{l}\text { U.S. Environmental Protection } \\
\text { Agency, } 1987\end{array}$ \\
\hline Water-extractable $\mathrm{SO}_{4}{ }^{2-}$ & Ion chromatography & Tabatabai and Dick, 1983 \\
\hline $\mathrm{NaH}_{2} \mathrm{PO}_{4}$-extractable $\mathrm{SO}_{4}{ }^{2-}$ & Ion chromatography & Tabatabai and Dick, 1983 \\
\hline
\end{tabular}

Table 2D. Data quality objectives for accuracy (expressed as percent error) and precision (expressed as a coefficient of variation) of soil analyses.

\begin{tabular}{lcc}
\hline Constituent or Property & $\begin{array}{c}\text { Accuracy } \\
\text { (percent error) }\end{array}$ & $\begin{array}{c}\text { Preclsion } \\
\text { (coefficiont of } \\
\text { variation) }\end{array}$ \\
\hline $\mathrm{pH}^{*}$ & 15 & 15 \\
Exchangeable bases & 10 & 10 \\
Exchangeable Al & 10 & 10 \\
Exchangeable acidity & 15 & 15 \\
$\mathrm{H}_{2} \mathrm{O}$ extractable $\mathrm{SO}_{4}{ }^{2-}$ & 10 & 10 \\
$\mathrm{NaH}_{2} \mathrm{PO}_{4}$ extractable $\mathrm{SO}_{4}{ }^{2-}$ & 10 & 10 \\
Total carbon & 15 & 15 \\
Total nitrogen & 15 & 15 \\
\hline
\end{tabular}

* Percent error and coefficients of variation are based on $\left[\mathrm{H}^{+}\right]$ 


\section{APPENDIX 3: QUALITY-ASSURANCE PLAN FOR STREAMFLOW MEASUREMENTS}

Field measurements and inspections of gagingstation operations will be done in accordance with guidelines set forth in and Rantz and others (1982), Hubbard (1992), and the USGS series, "Techniques of Water-Resources Investigations" (TWRI). For activities not adequately covered by the TWRI's, the Hydrologic Records Unit Chief or the District Surface-Water Specialist will be consulted.

Training of field personnel in standard field practices will be directed by the Data Unit Chief or designees. The instructor will be experienced and knowledgeable. Review and spot checking of field practices, installations, and record computations are the responsibility of the Data Unit Chief or his designees.

All field measurements and inspection notes will be recorded in a specified format as a permanent record. Field notes will be neat, readable, and leave no doubt as to interpretation.

Discharge measurements will be computed in the field and checked against the current rating curve after it has been established. If the measurement exceeds the normal tolerance ( \pm 5 percent), a check measurement will be made and computed unless otherwise directed by the Data Unit Chief. Measurements made when the control is affected by ice or other obvious obstructions (such as leaves or other debris) do not require check measurements.

Gaging stations will be inspected and discharge measurements made at least once every 6 weeks.
Inspections and measurements may be made in addition to scheduled visits and planned experiments when the control is affected by debris or ice, or curing high flows.

Streamflow records will be computed regularly and will follow a progress chart developed by the Data Unit Chief. Record computation will be dc $2 e$ in accordance with Rantz and others (1982) or the appropriate TWRI methods. All computations will be checked and reviewed.

Computer computations, data storage, and updating will follow procedures outlined in the ADAPS and WATSTORE User's Guides (Hubbard, 19:2) and checked carefully after each processing step to ensure accuracy and continuity between updates. Flow records for all stations will be checked to ensure that flows follow hydrologically consistent patterns. Subbasins in the Neversink basin will be comfared hydrographically, statistically, and by basin-runoff summaries, and significant variations will be investigated.

All computation, checking, and revier' functions will be done within the Albany, N.Y. office.

Streamflow data from gaging stations will be published annually. Data collection and analysis will be routinely monitored through project revieu's and input from the District specialists prior to report preparation. The project chief is responsible for correct interpretation of data to reach sound conclusions. 


\section{APPENDIX 4: DATA MANAGEMENT}

\section{Computer Resources}

The Neversink Watershed Study's computer resources consist of a 400 series Data General (DG) Aviion workstation networked to the New York District's central 6200 series DG server. Several networked personal computers are also available for use by project personnel. The total disk space on the DG workstation and server amounts to about 1.5 gigabytes. The personal computers (PC's) are linked to the DG server through SUN PCNFS networking software and, therefore, have access to the project data base. Several of the PC's are dedicated to capturing data from the chemistry laboratory's test equipment and processing them into the data base; the others are used by project personnel for data manipulation and analysis.

\section{Data Base}

The data-management activities are handled by SAS (Statistical Analysis Software) on the DG network under the UNIX operating system. SAS is also available to project personnel on the $\mathrm{PC}$, in both the DOS and WINDOWS versions. SAS was chosen for its datahandling capabilities as well as for its ability to analyze the data graphically, statistically, and otherwise. The specific data base being used is a modification of one written for the Episodic Response Project (ERP) and is running exclusively on the DG platform. This data base consists of two major components-the field data and the chemistry data. The former consists of one data set, and the latter consists of a data set for each constituent analyzed and a single data set representing the data from each of the individual constituent data sets. The data base also consists of several programs for input/ output and analysis that are being or have been modified on an "as-needed" basis.

\section{Data Capture}

Most of the chemistry laboratory's instruments are connected to PC's so that the data they generate can be captured in digital form and entered directly into the data base. Those instruments include a Perkin-Elmer 1100B atomic absorption spectrophotometer, a Dionex DX-100 ion chromatograph, a Radiometer VIT90 video titrator, a Fisher Scientific Accumet $925 \mathrm{pH} /$ ion meter, and a Lachat QuikChem AE flow-injection analyzer. The Dohrmann carbon analyzer has not yet been automated. Those instruments that do not have associated proprietary software to capture the data (the Radiometer titrator, the Perkin-Elmer atomic absorption spectrophotometer, and the Fisher $\mathrm{pH} / \mathrm{ic} \mathrm{n}$ meter) have had custom software written by project personnel for this task. The Fisher $\mathrm{pH} /$ ion uses a Quick-Basic program to capture output, whereas the Perkin-Elmer and the Radiometer use the Procomm communication software's Aspect script language. Import of the electronic data files into the data base is done thmugh SAS programming.

As stated above, the Perkin-Elmer and the Radiometer VIT90 use the Procomm Aspect programming language to capture instrument data to a log file. The programs provide a menu-driven system for frocessing data from the instrument and reside on the local PC. The log files are stored in a directory with th $:$ path C:Istorelidentifiertmmddyy, where "mmddyy" is current date, and "identifier" is either "anc" for the Radiometer or "aa" for the Perkin-Elmer. For the Perkin-Elmer, this program is named aa.asp, and for the Radiometer, this program is named anc.asp. Log files are named after the constituent being analyzed and are suffixed with the run number. For example, the first run of the Radiometer for $01 / 01 / 93$ would produce the $\log$ file C:Istorelanci010193lanc1. These programs also use " $C$ " programs to modify the log files into a format that can be edited by the analyst and be read directly into the SAS data base. The resulting files are named after the current log file name with a ".dat" extension and are stored in the same directory as the given $\log$ file.

\section{Data Verification}

Accuracy of the data base is verified th ough two independent mechanisms, depending on whather the data are input manually or electronically. All written field data are typed into the data base twice. The SAS compare procedure is then run on the data to identify differences in the duplicate data sets. Differences are resolved by referral to the field-data forms. Data that are electronically transferred into the data b'se are automatically checked for duplicate sample serial numbers and illegal site-identification codes. A separate file containing legal site-identification coder is maintained to ensure that only correct codes are used. Outof-limits values for each chemical analysis have also been set within the program. Periodically the data-base 
manager reviews completed segments of the data base to determine whether any values are missing.

\section{Software}

The project's DG has a disk partition dedicated to storage of DG and PC software. The software includes SAS for DOS, SAS for Windows, Exceed X11 GUI, Excel for Windows, and Quick C. Also in this directory is a directory called "work," which includes a PC SAS program directory, an SAS initialization directory, and a storage directory for Lotus " "prn" files.

\section{Backup}

Backup procedures currently consist of three measures:

- The complete data base is copied daily from the work-station disk to a disk located on the DG server, through a "crontab" job

- The server disk is backed up to tape wertly by the computer unit of the Albany office.

- The data base residing on the workstaticn is also backed up to tape once every 3 months. 